\title{
A COMPANHIA GERAL DO COMÉRCIO DO BRASIL (1649-1720)
}

\section{Subsídios para a História Econômica de Portugal e do Brasil}

\author{
(Conclusão)
}

\section{V}

\section{A COMPANHIA DEPOIS DE INCORPORADA NO ESTADO}

\section{(1664-1720)}

1 - A vida da Companhia de Comércio, depois que se integra no Estado e passa a estabelecimento, autônomo embora, da Corôa, perde interêsse, para o nosso ponto de vista. $O$ grande perigo par ミr a navegação passou; e o açúcar do Brasil, cuja cotaçáo baixa em Londres e que sofre a concorrência doutros açúcares no mercado mundial, já não tem a mesma importância para a econom mia nacional, que tivera no reinado de $D$. João $I V$. Vai subindo - valor do tabaco - e a mineração destronará de vez o açúcar. Para comboiar as frotas já não são necessárias 18 naus de fôrçạ bəstam 10, bastam 5 (346).... Os gastos são, pois, muito menores; a esquadra pode efetuar-se anualmente. Assim, temos noticia de frota que sai de Lisboa a 30 de março de 1665 , com 20 navios mercantes, comboiados por um só de guerra, a que se juntarão mais 2 - um que parte do Tejo a 6 de maio e outro que se fabricou no Rio de Janeiro - para escolta no torna-viagem (347); entra em 20 de outubro, com 40 navios de carga (348); outra se efetua em 1666 (sai a 15 de março a armada da Junta para trazê-la do Brasil) (349); a 26 da abril de 1667, parte pera o Brasil frota de 60 velas, devidamente escoltada (350), a qual reentra em Lisboa a 28 de novembro (351). Em 1668 não sabemos se houve frota; mas houve-a em 1669, de 50 embarcaçóes (352); e em 1670 (che-

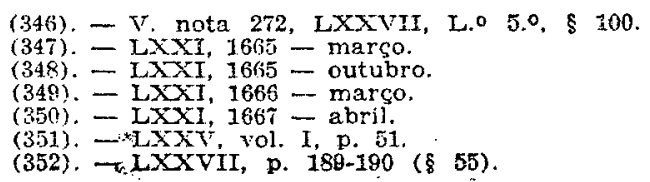


ga in Reino em fins de setembro, começcs de outubro) (353); em 1671 (aportam a Lisboa, a do Rio de Janeiro en outubro, $\varepsilon$ em dezembro a da Bahia e Pernambuco) (354); e em 1672 (chega do Brasil em novembro, atrazada pelo temporal) (355); e em 1673 (al frota da Bahia e Pernambuco entra nos portos do Reino em outubro, e a do Rio em novembro) (356).

2 - Em 1672 a Junta de Comércio fôra mais una vez refó mada pelo Regimento de 19 de setembro (357); nada de fundamental se alterava: somente se providenciava para uma melhor administração.

\section{VI \\ EXTINCẼO DA JUNTA}

$(1720)$

1 - Eu El-Rei faço saber, cos que êste alvará em forma de lei virem, que, sendc-me presente que a Junta da Companhial Geral do Comércio do Brasil... para o fim de aprestat os navios de guerra para conduzir e defender as frotas, se não acha... com possibilidade para satisfazer o dito encargo, como me tem representado por consultas de 21 de janeiro de 1713,19 de máio de 1715 . 7 de novembro de 1719 e 22 do dito mês, e ano, além disto, tem contraído grandes empenhos a que não pode dar satisfaçăo, antes crescem cada vez mais, náo se pagando os juros do dinheiro que tomou a mesma Junta para acudir a muitas despesas que lhe eram precisas, nem se satisfazendo as letras que para o mesmo fim se sacaram sôbre a mesma Junta, tendo muita parte dêste dinheiro aplicação para muites obras pias e de grande obrigação. E considerando que éstes empenhos e dívidas se aumentavam cada vez mais, ccm grands número de oficiais e pessoas que se ocupavam nos ministérios da dita Junta podendo-se escusar a despesa que com elas se fazia para com a sua importáncia ajudar o seu desempenho. Fui servido resolver... que se extinga a dita Junta e se suprimam todos os cargos: lugares, ofícios e ccupaçōes de que se compunham e tela tram dependentes, e pot êste alvärá em forma de lei a hei por extinta e suprimidos..." (358). Assim, em 1 de fevereiro de 1720 , D. João V encerrava a histórie da Companhia do Comércio do Brasil.

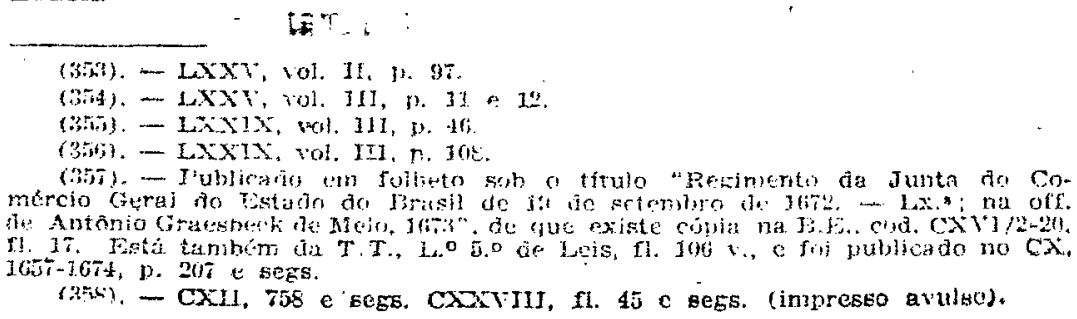


Enquanto sociedsde particular ccnsumira talvez partel do capital dos sócios; agora, repartição do Estado, era pior, porque consumia o dinheiro dos credores...

Os comboios continuavam, se bem que de só 5 navics de guerra (2 para a frota da Bahia, 2 para a do Rio e 1 para a de Pernambuco), mas a administração dêles correria pelo Conselho de Fazenda e os serviços necessários pelos oficiais dos Armazens reais, embora: com escrita separada; a Infantaria de Marinha da Junta unia-se à da Armada Real. Ao pagamento das dívidas aplicavam-se - produto da verda das casas da Junta, o rendimento do contrato do pau Brasil e o impôsto especial, para êsse fim estabelecido, de $1 \%$ do ouro que viesse do Brasil, ainda o que pertencesse à fazenda real (359). Pera o efeito submetia-se o curo a um registo, sob pssadas penas; mas deve ter havido fugas repetidas, pois, mandando-se, por alvará de 20-3-1720 (360), confiscar o ouro vindo sem registro, voltava a providenciar-se sôbre o assunto em 26 de outubro do mesmo ano (61), por lei de 24-12-1734 (362) e por lei ds 28-2-1736 (363).

\section{VII \\ CONCLUSÄO}

Extinta a Companhia, fala-se dela com saudade, encarecendo os serviços que prestcu à nação... Assim num parecer ançnimo sôbre a proposta de uma nova Companhia colonisl, que deve ter sido $\epsilon$ scrito pouco depois da dissolução da Junta Comércial (364); assim noutro parecer, $d_{\equiv} 12$ de fevereiro de 1728 , de Venceslau Pereira da Silva, "em que se propõem os meios mais convenientes para suspender e: ruina dos três principais gêneros do comércio do Brasil, açúcar, tabaco e sola" (365); assim na "História da América Portuguêsa", de Sebastiäo da Rocha Pita (366)....

Feito o balanço gare1 da atuação da Companhia, encontramonos, no seu passivo, com as muitas moléstias dos moradores do Brasil, já relatadas. E também com as cos pevos da Metrópole. Viana do Castelo, por exemplo, vê o número de ssus fogos reduz:dus de siscentos e os seus impostos eduansircs psssarem de 20 contos a $240.000 \mathrm{rs}$., em poucss anos (367), porque, fazsndo os combsios de e para Lisboa, e monopolizendo os 4 gêneros, a Companhia centraliza o cimércio ccm o Brasil na capital em prejuizs. dos restantes portos (368). M:s não foram os cristênos novos os que menos sofreram. A isenção do confisco só não se pods dizer

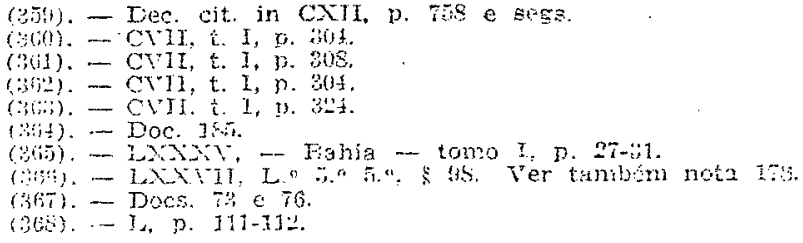


que houvesse sido um ludibrio porque nada autoriza a supor uma intenção reservada na mente de $\mathrm{D}$. João $\mathrm{IV}$, ao promulgar o alvará de 6 de fevereiro de 1649. Mas que a promessa solenemente $f \in i t a$ tos judeus nunca se cumpriu mostrcu-o Lúcio de Azevedo: "Também desde os primeiros tempos faltara o govérno ao convênio sôbre a fazenda dos presos. Viu-se como, contra o disposto no alvará de isençäo, ainda no período inicial do sistema se procedera aos arrolımentos; depois, por modificaçōes sucessivamente introduzidas, se entregaram os acervos aos depositários gerais, mais tarde aos próprios encarregados do fisco. De onde se vé como desprezara o govêrno as promessas solenes, da mesma forma que os homens de negócios faltavam aos encargos. Em 1657, os depósitos em Lisboa montavam a 250.000 cruzados, em pratas, ouro, moeda e dívidas, fora: os açúcares e outros géneros das colônias, e os bens de raiz, com que se perfazia dobrada soma; em Evora acima de 45 mil; Coimbra daria 25. São os números do Conselho de Fazenda. Se era propriedade confiscada por sentença devia devolver-se aos reus ou, quando incursos na pena de morte, a seus herdeiros. $\bar{A}$ Corôa tocava sòmente a dos pertinazes, que morriam renegando a fé católica, e essa esteria muito aquém de semelhante valor. O ato de Regéncia, retardado por escrúpulos, não fôra em verdade rnais que o natural seguimento da apreensão, contrária ao convênio" (369).

Por outro lado, só uma única vez al Companhia distribuiu dividendos (370); e o capital subscrito, sôbre quase nada ter rendido aos acionistas durante 15 anos, ainda no final thes é restituido, não em dinheiro, mas em padróes de juro, cujo valor real devia ser inferior ao nominal (371).

Pode ser que os mais poderosos déies, os que constituiam os corpos gerentes, tirassem a compensaçāo por cutra banda; além dos seus ordenados (372), talvez tivessem suas negociatas; sabemos que a Companhia exportava açúcares e cutros produtos coloniais para o estrangeiro (373), - acaso provenientes, ao menos em parte, de escambo com os géneros estanque e do preço de fretes, já que o açúcar era, a bem dizer, a moeda brasileira (374) -, em quantidades e valores apreciaveis (375), se bem ignoremos em que condições; insinuava-se, contudo, que ésse comércio não era em benefício dos acionistas... (376).

(369). - VII, p. 278.

(370). - 15\%: CV, vol. YI, p. 385.

(371). - XCV], t. I, p. 233-53.1.

$\left(\hat{3} \bar{z}_{2}\right.$ ). - Pelos vencimentos estabeleciaos na reforma de 1602 (V. cap. IV) ,odemos ajuizar dos anteriores.

(373). - Docs. 40 e si.

(374). - For exemplú guando D. João $\Pi$ convida, em 1648 , os estrangeiros

a levarem mercadorias do Brasil, promete o pagamento em acucar. XCl, $1,207$. (375) - Docs. $86 \mathrm{6}$ \& $\mathrm{si}$.

(376). - Doc. 87; doc. 73. E o que torna mais suspeita a açáo dos diretores é o nào darem contas a pretexto do sefrido do negjicio (L, $\mathrm{p}$. $12 \mathrm{~s}$; CV, t.. VI, p. 386). 
Mas o ativo é nitidamente favorável à Companhia. Pondo de parte os vários serviços, de meños monta, que prestou, temos de creditar-lhe o haver assegurado a navegação para o Brasil.

De 1649 a 1664 realizou 9 frotas; comparanóo os números da produção brasileira averiguados por Simonsen com os das cargas trazidas por algumas frotas, que antes se indicarem, tendo em conta os barcos que realizaram a carreira sem combôio, quer mandados pela Companhiat (377), ou autcrizados pelo govêrno (378), quer clandestinamente (379), podemos, decerto, fixar a média anual de açúcar importado em Portugal em 800 ou $900 \mathrm{mil}$ arrobas (metade da: quantidade indicada por normal no $\$ 3$ do cap. I) (380). Descontado o consumo, ficariam, à vontade, 500.000 arrobas livros para exportação, no valor de mais de 1.000 contos (381.) - suficiente para cobrir a totalidade, ou a maior parte, das nossas necessidades de importação (382). A quantidade anual saída do Brasil aumentou, decerto, depois, quer em conseqüéncia da recuperação de Pernambuco, quer por haver frota anual; mas também o preço do açúcar descera (383), e a sua colocação no estrangeiro se tornara mais difícil, por causa da concorrência (384).

Ora, sem navegação, näo teria vindo tal açúcar, e muito maior teria sido o prejuízo dos povos, privados de comércio colonial e privados do comércio externo que aquêle possibilitava. O nível de vida geral teria descido. E, pior que tudo, perder-se-ia o Brasil - e não se manteria a independência.

Do modo que, em conclusão, podemos dizer que a Companhia Geral do Comércio do Brasil foi num grave momento da nossa história um fator importante da manutenção da independência.

GUSTAVO DE FREITAS

Professor do Ensino Técnico em Lisboa.

(377). - V. nota 316 .

$(378)$ - Docs. 95,129 e 132

(̇́79). - Que eram muitos provam-no, não só as queixas da Companhia, como, sobretudo, a multiplicidade das leis proibitivas, a que fí aludimos. $T$. também doc. 141 .

(360) - Na consulta do Conselho. da Fazenda de 2 de janeiro de 1657 calcula-se em 35.000 caixas (1.225.000 arrobas) por ano a importaça dos anos anteriores (L, p. 124).

(381.). - nota $23 ;$ v. $\$ 3.0$ do Cap. I.

(382) - -53.0 do Cap. I e nota 20 .

(383). - LV, vol. I, p. 170-1i1.

$(384)$. LX, passins. 


\section{REFERENCIAS (1)}

\section{A.) BIBLIOGRAFIA}

\section{a) CATALOGOS}

- ANSELMO (Antônio) - Bibliografia das Bibliografias Portuguêsas. Ix." 1923.

- MARQUES (João Martins da Silva) - Arquivo Nacional da Torre do Tombo (Eusaio de am manual de Heuristica e arquivologia) - I Index Indicum. Lx." 1935.

- Inventário da Biblioteca Nacional de Lisboa - Secção XIII - Mss. Col. Pombalina. Lx.", 1889.

- Inventário da Biblioteca Nacional de Lisboa - Secção XIII - Mssa. Fundo Gerai. Lx. 1896.

- Biblioteca Nacional - Exposição Bibliogräfica da Restauração - Catálogos - Lx." vol. I, 1940, vol. II, 1941.

- ENES (Ernesto) e FITZLER (H.) - A Secção Uitramarina da Biblioteca Nacional de Lisboa. Lx.".

- ALMEIDA (Eduardo de Castro e) - Inventário dos documentos relativos ao Brasil existentes no Arquivo de Marinha e Ulltramar. Rio de Janeiro, 8 vols., 1913 a 1921 .

- Indice dos Manuscritos pertencentes à Bibliateca da Universidade (de Coimbra), in Archivo Bibliografico. Coimbra, 1877.

- MORAIS (Francisco) - Catálogo dos Manuscritos da Biblioteca Geral da Universidade de Coimbra relativos ao Brasil. Coimbra, 1941.

- RIVARA (Joaquim Heliodoro da Cunha) - Catálogo dos Manuscritos da Biblioteca Pública Eborense. Lisboa, 3 vols., 1850-1870.

- Catálogo dos Manuscritos da Biblioteca Nacional (do Rio de Janeiro) Parte I - Manuscritos relativos ao Brasil; in Annaes da Biblioteca do Rio de Janeiro, vol. IV (1877-1878).-

- Côrtes do Reino de Portugal - Inventário da documentação existente... Lx.", 1940.

- SIMOESS (Carlos Galvão) - Subsidios para uma Bibliografia das Come-

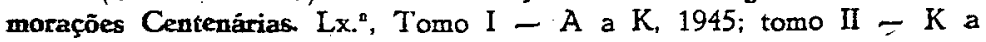
$\mathrm{X}, 1947$.

(1). - ABREVIATCRAS:

A.C. - Biblioteca da Academia das Ciências de Lisboa.

A.H.C. - Arquivo Esistórico Colonial.

B.A. - Bibjioteca da Ajuda.

B.E. - Arquivo Distrital de Evora - Biblioteca Pública.

B.N. - Biblioteca Nacional de Lisboa.

T.T. - Arquivo Nacional da Torre do Tombo. 


\section{b) OBRAS}

I - PLNEIDA (Fortunato de) - Histöria de Pörtugal, Vol. V, Coimbra. $192 \hat{8}$.

II - AMZALAC (Woses Bensabat) - Do Estudo e da Evoluçäo das Dos trines Económicas en Portugal, in Revista do lastituto Superior do Crom ziercio de Lisboa LX.", atso XI, Abril, 1928.

III - AZEVEDO (J. Lácio de) - Aiguns escritos apócrifos inéditos e menos conhecidos do Padre Antonio Vieira. Combra. 1915.

IV - NZEVEDO iJ Luco de - Dezanove cartas inciditas do Padre Artonio Vieira, in Boletin dia Segunda Classe da Academia das Cienciats de Lisbua, vol. $X$ (1915), Coinbra, 1917, p. $384-483$ (Estudo, que antecede a publicaçầo dás cartas).

$V$ - AZEVEDO (J. Lício de) - Epocas de Portugal Economico. 2." $\mathrm{Lx}, 1947$

VI - AZEVEDO (J. Lúcio de) - História de Antônio Vieira Vol. $j$, L... 1918

VII - AZEVEDO (T. Lücio de) - História dos Cristäos Novos Portuguên ses, Lx.", j921.

VIII - AZEVEDO (J. Lücio de) - Os Jesuitas a Inquisição em conflito no século XVI, in Boletin da Segunda Classe da Academia das Ciencias de Lisboa, rol. V. (1915-1916), Coimbra, 1917.

XX - BAISO (António) - Ei-Kei D. João IV e a Inquisição, in Anais dá Acedemia Portíguêsa de História - Ciclo da Restauraçáo, vot. VI. Ix: : 1942, p. 9 e seos.

X - EERREDO (Bemardo Pereira de) - Anais Históricos do Estado do Marantão. Lx: ${ }^{2}, 1740$.

XI - BLUTEAU (Raphael) - Vocabulário Portuguez e Latino, $\delta$ vols. Coimbra e Lx." 1712 a 1721 , mais 2 de Suplemento $\mathrm{Lx}^{2}, 1727$ e 1728 .

XII - CALMON (Pedro) - Brasil Politico-Militar, in A Restauração e o Imperio Colonial Português. Lx. ${ }^{n}, 1940$.

XII - CAKVALHO (Artur Morais de) - Companhias de Colowizacão. Coimbro. 1903.

XIV - CARVALHO (Augusto da Silva) - As diferentes edições das "Nótżcias Recônditas da Inquisição". in Anais das Bibliotecas e Arquivos, vol. 17.0 (1940), n.0 $67-68$.

XV - CARVALHO (José Liberato Freire de) - Ensaio histórico-político sćbre a constituição e govêrno do Reino de Portugal ... Lx." 1843.

XVI - CARVALHO (Tito Augusto de) - As Companbias Portuguésas de Colonização. Lx:" 1902.

XVII - CAVALHEIRO (Rodrigues) - A Colaboração da Metrópole na Reconquista do Brasil, in Congresso do Mundo Português - Publicasies - vol. IX, Lx.", 1940.

XVIII - CAVALHEIRO (Rodrigues) - Os Judeus e a Restauração in Ocidente, vol. XI $(1940)$.

XIX - CAVALHEIRO (Rodrigues) - 1640 - Richelieu e o Duque de Bragança. Lx. ${ }^{\mathrm{F}}, 1942$.

$X X$ - CONCEIÇAO (Fr. Cláudio da) - Gabinete Histórico. Tomo N. Lx.": 1819.

XXI - COQUELIN (Ch.) - Compagnies privilegieses, in Dictionnaire de lEconomic Politique. Tomo I (A-1), Paris. 1852.

XXI - CORTESÃO (Jäme) - Dominio Ultramarino, in Histónia de Portugai - Edição Monumental. Vol Vi, Barcelos, 1934.

XXII - CORTEZFO (Jaime) - A Geografia e a Economia da Restauração. $L x^{*}, 1940$. 
XXIV - DAY (Clive) - Historia del Comercio. Versión española de Teodoro Ortiz, Tomo I, México, 1941.

XXV - DUARTE (Ricardo Teixeira) - Comentário ao Titaio XIl, Parte I, Livro II do Código Comercial Portuguez que se inscreve das Companhias, Sociedades e Parcerias Comerciais. Lx." 1872.

XXVI - EÇA (Vicente M. M. C. Almeida d) - Normas Econômicas da Colonização Postuguêsa até 1808. Coimbra, 1921.

XXVII - FANFANI (Amintore) - Storia Economica. Milano, 1940.

XXVIII - FIGUEIREDO (Fidelino de) - Historia da Litteratura Classica (Continuação da 2." epocha: 1580-1756. 3.a epocha: 1756-1825). 3.a ed. revista, Lx.", 1931. (Cap. XI - O Padre Antonio Vieira e a eloquencia).

XXIX - FLEIUSS (Max) - Apostilas de História do Brasil, in Revista do Instituto Histórico e Geográfico Brasileiro, Rio de Janeiro, vol. especial de 1933.

XXX - FONSECA (Quirino da) - Os Portuguêses no Mar - vol. I Ementa Histórica das Naus Portuguêsas. S.l.n.d.

XXXI - HAUSER (Henri) - Les débuts du capitalisme. Nouv. éd. Paris, 193.1.

XXXII - LEROY-BEALILIEU (Paul) - De la colonisation chez les peuples modernes, 6ème éd., Paris, 1908, 2 tomos.

XXXIII - LIMA (Durval Pires de) - Ainda algumas observaçōes àcêrca da Invencivel Armada, in Congresso do Mundo Português - Publicaçôes vol. VI. $L x . "$. 1940.

XXXIV - LIMA (Durval Pires de) - A defesa do Brasil de 1603 a 1661, in Congresso do Mundo Portugués - Pubilicações, vol. IX, Lx.", 1940.

XXXV - LIMA (Durval Pires de) - O Oriente e a África desde a Res. tauração a Pombal. Lx.", 1946.

XXXVI - LINDEN (Herman Vander) - L'Hégémonie Européenne - Pé. riode Italo-Espagnole. Paris, 1936 (Tomo X da Col. "Histoire du Monde").

XXXVII - LYON CAEN (Ch.) \& RENAUITT (L.) - Manuel de Droit Commercial, 15ème, éd. avec la colaboraticn de André AMIAUD. París. 1928.

XXXVIII - MATOS (Gastão de Melo de) - Nos Bastidores da Política Seiscentista - D. Sebastião César de Menezes. Lx. ${ }^{2} \cdot 1941$.

XXXIX - MATOS (Gastão de Melo de) - Notícias do Terço da Armada Real, in Anais de Club Militar Naval. Lx.", ano de 1931, n. ${ }^{\circ}$ de outubrodezembro.

XL - MATOS (Gastão de Melo de) - O Sentido da Crise Poltica de 1657. Lx. 1944.

XII - MEREA (Manuel Paulo) - O Poder Real e as Côrtes. Coimbra, 1923.

XIII - MURLAS (Manuel) - Os dominios ultramarinos portuguêses e a administração ultramarina, in Congresso do Mundo Português - Publicações - vol. VI, tomo $1 . \therefore$

XIIII - PEREIRA (Gabriel) - Os Judeus portuguêses e o comércio interna. cional, in $\mathbf{O}^{-}$Mundo Económico, ano I, n." 10.

XITV - PERES (Damião) - O Império Português na Restauração, in $\mathbf{A}$ Restauração e o Império Colonial Português. Lx.", 1940.

XLV - PERES (Damiâo) - Organizaçāo Econômica, in História de Portugal - Edição Monumental. Vol. VI, Barcelos, 1934.

XIVI - PIRENNE (Jacques) - Les Grands Courants de l'Histoire Universelie. Vol. II, Neuchatel, 1944.

XIVII - POMBO (José Francisco da Rocha) - História do Brasil. Vol. V da 3.* ed., de Benjamim de Aguila, Rio de Janeiro, s.d.; vol. Il da ed. Anuário do Brasil, Rio de Janeiro, s.d.

XLVIII - PRECLIN (Edmond) et TAPIE (Victor-L.) - Le XVII siècle. 2." ed., Paris, 1949. (Col. "Clio"). 
XLIX - PRESTAGE (Edgar) - As Relações Diplomáticas de Portugal com a França, Inglaterra e Holanda de 1640 a 1668 . Trad. de A. F. de Carvalho, Coimbra, 1928.

L - PRESTAGE (Edgar) - Três Consultas do Conselho da Fazenda de 1656 a 1657, in Revista de História, vol. 9. Lx.", 1920.

LI - REGO (A. da Silva) - A dupla restauração de Angola. Lisboa, 1948.

Lil - RIBEIRO (José Silvestre) - As Córtes Pcrtuguêsas Antigas, in $\mathbf{0}$ Panorama, vol. $17, \mathrm{Lx}^{\mathrm{n}}, 1867$, p. $18,25,46,82,94,118,137,162$, 202, 221.

LIII - RODRIGUES (Pe. Francisco) - O padre Antônio Vieira - Contradições e aplausos, in Revista de História, vol, XI (1922).

LN - SANTA RTA (1. Gonçalo de) - O regime comerciai e jurídico. As frotas e as companhias coloniais; organização financeira"e judicial no Ultramar, in História da Expansão Portuguêsa no Mundo, vol. III, Lx. ${ }^{2}, 1940$.

LV - SCELLE (Georges) - La Traite Négrière aux Indes de Castille Contrats et Traités d'Assiento. París, 1906, 2 tomos.

LVI - SOHEFER (Henrique) - História de Portugal, ed. portuguésa por J. Pereira de SAMPAIO (BRUNO). Vol. IV. Pôrto. 1898.

IVII - SEEE (Henri) - Origem y. Evolución del capitalismo moderno. (Trad. del texto fr. por Macedonio GARZA, revisada y puesta de acuerdo con las trad. ingl. e ital. - corregidas y aumentadas por el autor por Antonio Castro LEAL). México, 1937.

LVIII - SERGIO (Antônio) - Antologia dos Economistas Portuguèses, Lx. ${ }^{n}, 1924$.

LIX - SILVA (Luis Augusto Rebelo da) - História de Portugal nos séculos XVII e XVIII. Tomo IV, Lx. ${ }^{\mathrm{N}}, 1869$.

IX - SIMONSEN (Roberto C.) - História Econômica do Brasil. 1500-1820. S. Paulo, 1937, 2 tomos.

IXI - SOUSA (A. Botelho de) - Subsidios para a História das Guerras da Restauração por Mar no Além-Mar. Vol. I. Lx:" 1940.

LXII - TELES (J. H. Correa) - Digesto Postuguez. Tomo III, Lx * 1836.

LXIII - VARHANGEN (Pôrto Seguro) - História das Lutas com os Ho landeses no Brasil desde 1624 a 1654. Viena d'Austria, 1871.

LXIV - VASCONCELOS (Frazão de) - A Marinha da Corôa de Portuga! no tempo dos Filipes, in Congresso do Mundo Português - Publicaçóes -, vol. VI, Lx.", 1940.

LXV - VASCONCELOS (Frazão de) - De Re Nautica (Galeões da Corôa de Portugal no tempo dos Filipes), in Anais do Club Militar Naval, Lx. ${ }^{\mathrm{n}}$, ano de 1931, n. ${ }^{\circ}$ de março e abril.

LXVI - VELOSO (Queirós) - O Brasil durante os 60 anos da admiaistração filipina, in Congresso do Mundo Portugués - Publicaçōes, vol. IX, $\operatorname{Lx}^{8} .1940$.

\section{B.) PONTES}

\section{a) NARRATTVAS}

LXVII - CUNHA (D. Luiz da) - Testamento Politico. . Ed. pref. por Manuel Mendes, Lx." 1943.

LXVIII - D. Afonso VI. Pôrto, 1940. (Atribuida a Antônio de Sousa de MACEDO, e a Manuel Severim de FARIA. Apresentada por Eduardo Brazão).

LXIX - FARIA (Manuel Severim de) - Noticias de Portugal. 2." impressão. Lx." 1740. 
LXX - FREIRE (Francisco de Brito) - Viage da Armada da Companhia do Comercio e Frotas do Estado do Brasil a cargo do General..., em Nova Luzitania (B.N. - Res. 422 A.).

LXXI - MACEDO (Antonio de Sousa de) - Mercurio Portuguez, com as novas da guerra entre Portugal e Castela. Começa no principio do ano de 1663 por... Lx.", 1663 (B.N. - Res. 110 v.).

LXXII - MELO (D. Francisco Manuel de) - Cartas Familiares. Lx. ${ }^{\mathrm{a}}, 1752$. Centuria 3.". carta 61." (de 15 de fevereiro de 1649).

LXXIII - Memórias sôbre Portugal no reinado de D. Pedro II (por Edgar PRESTAGE). Lx.", 1935 - (Separata do Arquivo Histórico de Portugal).

LXXIV - MENEZES (D. Luis de) - História de Portugal Restaurado. Parte $\mathrm{L}$ tomo II, Lx.", 1943.

LXXV - Monstruosidades do tempo e da fortuna. Nova ed. publicada sob a direção de Damião PERES, 4 vols., Pôrto, 1938-1939.

LXXVI - P. G. (P. Groguard) - La Couronne du Portugal. Turim, 1682.

LXXVII - PITTA (Sebastiāo da Rocha) - História da América Portuguêsa. 2." ed., Lx.", 1880.

LXXVIII - Relaçam diaria do sitio e tomada... do Recife... (E seu autor Antonio Barbosa BACELAR). Lx.", 1654. (B. N. - Res. 1559 p., n.: 10).

LXXIX - Relation de la Caur de Portugal sous Pedro II... Traduite de l'anglais. Tcme 1.e", Amsterdam, 1702, tome second, Amsterdam, 1702.

LXXX - SOUSA (D. Antonio Caetano de) - Historia Genealogica da Casa Real Portuguesa. Tomo VII.

I.XXXI - VIEIRA (atribuida ao Pe. Antônio) - A Arte de Furtar. 10. ed. prefaciada... por Jaime Brasil, Lx.2, 1937. (E o seu autor O Pe. Manuel da COSTA, cfr. doc. publicado pelo $\mathrm{Pe}$. Francisco Rodrigues, em O Padre Manuel da Costa autor de Arte de Furtar, Pórto, 1944).

LXXXII - VIEIRA (Pe. António) - Obras Inéditas. Tomos I e II, Lx. 1856: tomo III, Lx.", 1857.

LXXXIII - VIEIRA (Pe. António) - Papel politico que se deu a El-Rei D. Pedro II, em ocasião que se convocaram Cortes para se lançar um tributo, que servisse para desempenho do Reino - Pelo... Em nome dos Rusticos da Serra da Estrela. Lx." 1838.

LXXXIV - VIEIRA (Pe. Antônio) - Sermões. Vol. 8., Lx. $^{a} 1908$.

\section{b) DIPLOMATICAS}

\section{1) Impressas}

LXXXV - ALMEIDA (Eduardo de Castro e) - Inventário dos documentos relativos ao Brasil existentes no Arquivo de Marinha e Uitramar. Rio de Janeiro, 8 vols., 1913 a 1921. (Transcreve alguns documentos, sumaria outros).

LXXXVI - ANDERSEN (Maria Josefina) - O Espirito varonil e régio da Rainha D. Luisa de Gusmão - Campanha do Alentejo - Cartas inéditas dos anos de $165 \overline{7}, 1658,1661$ e 1662), in $O$ Instituto, vol. 69. (1940).

EXXXVII - AZEVEDO (J. Lúcio de) - Cartas do Pe. Antônio Vieira. Vol. I, Coimbra, 1925.

- AZEVEDO (J. Lúcio de) - Dezanove cartas inéditas do Pe. Antônio Vieira, in Boletion da Segunda Classe da Academia das Ciências de $\mathrm{Lis}$ boa, vol. X (1915-1916), Coimbra 1917. - Já cit. na Bibliografia (IVT).

- AZEVEDO (J. Lúcio de) - Épocas de Portugal Econômico. 2. ${ }^{a}$ ed., Lx. 1947. (Apêndice, p. 461-471). - Já cit. na Bibliografia (V.). 
- AZEVEDO (J. Lúcio de) - Histốria de Antônio Vieira. Vol. I. Lx.", 1918. (Extrato de carta, a p. 144-145. e Apêndice n. ${ }^{\circ}$ 2, a p. 377-385). - Já cit. na Bibliografia (VI).

- AZEVEDO (J. Lúcio de) - História dos Cristãos Novos Portuguêses. Lx. ${ }^{2}$, 1921. (Apêndice, p. 443-496). - Já cit. na Bibliografia (VII).

- AZEVEDO (J. Lúcio de) - Os Jesuitas e a Inquisição em conflito no século XVII, in Boletim da Segunda Classe da Academia das Ciências de Lisboa, vol. X (1915-1916), Coimbra, 1917. (Sumários e extratos de documentos). - Já cit. na Bibliografia (VIII).

- BAIÁO (Antônio) - El-Rei D. João IV e a Inquisição, in Anais da Academia Portuguêsa de História-Ciclo da Restauração, vol. VI, Lx.", 1942. p. 9 e segs. (Alguns documentos copiados ou extratados). - Já cit. na Bibliografia (IX).

LXXXVIII - BRAZAO (Eduardo) - Algumas cartas de D. João IV, in Revista dos Centenários, ano $1 .^{\circ}$, Fasc. 11 (30-nov.-1939).

LXXXIX - BRAZAO (Eduardo) - Alguns documentos da Biblioteca da Ajuda sôbre a Restauração, in Ocidente, vols. 8. e 10.0 (1939), Lx. ${ }^{\circ}$.

XC - Catálogo dos Manuscritos da Biblioteca Nacional (do Rio de Janeiro) - Parte I - Manuscritos relativos ao Brasil, in Anais da Biblioteca do Rio de Janeiro, vol. IV (1877-1878). (Sumaria documentos).

XCI - COELHO (P. M. Laranjo) - Cartas de El-Rei D. João IV ao Conde da Vidigueira (Marquês de Niza) embaixador em França. Vol. II, $\mathrm{Lx}^{2}, 1942$.

XCII - COELHO (P. M. Laranjo) - Cartas de El-Rei D. João IV para diversas autoridades do Reino. Lx." 1940.

XCIII - COELHO (P. M. Laranjo) - Cartas dos Governadores da Província do Alentejo a El-Rei D. Afonso VI. Vol. 3., Lx.", 1940.

XCTV - Collecçáo da Legislação Antiga e Moderna do Reino de Portugal (Ordenações e Leis do Reino de Portugal. Publicadas em 1603. Livro Quarto). Ed. de Coimbra, 1790.

XCV - Cojlecção de Leis - 1539-1699. (B. N. Res. 84-A).

XCVI - Colleccaão de Leis da Divida Publica Portuguesa coordenada e pubi:cada pela Junta do Credito Publico. Primeira parte - Divida interna. Tomo I, Lx. ${ }^{\mathrm{B}}, 1885$.

XCVII - Corpo Diplomatico Portuguez. . Vol. 13. ${ }^{\circ}$, LX. ${ }^{n}, 1907$.

XCVIII - Documentos dos Arquivos Portuguêses que importam ao Brasil. Lx.", ed. do S.N.I., n. ${ }^{\circ} 2$ e n..$^{\circ}$ de 11-jan.-1946.

XCIX - Documentos para a História. - O govêrno de Felix José Machado na Capitania de Pernambuco, in Revista do Instituto Arqueológico, Histórico e Geogräfico Pernambucano, vol. XVI, n. ${ }^{\circ}$ 83-86.

C - FERREIRA (Carlos Alberto) - Subsidios para a História do Brasil na ćpoca de D. João IV, in Congresso do Mundo Português - Publicaçōes, vol. IX, Lx." ${ }^{2}$ 1940. (Sumaria documentos).

- FREIRE (Francisco de Brito) - Regimento que... mandou guardar aos navios de conserva, in Nova Luzitania. Viage da Armada da Companinia do Comercio... (B.N., Res. 422 A.). - Já cit. em Fontes Narrativas (LXX).

CI - FREIRE (Francisco de Brito) - Sôbre o bom govêrno e guerra do Brasil, in Ocidente, vol. 9. ${ }^{\circ} \mathrm{Lx} .^{\mathrm{N}}, 1940$.

CII - Indice dos Manuscritos pertencentes à Biblioteca da Universidade (de Coimbra), in Archivo Bibliografico, Coimbra, 1877. (Sumaria documentos).

CIII - Leis. (B.N. - Res. 100-A.).

- LIMA (Durval Pires de) - A defesa do Brasil de 1605 a 1661, in Congresso do Mundo Português - Publicações, vol. IX, Lx.". 1940. (Sumaria documentos). - Já cit. na Bobliografia (XXXIV). 
CIV - MORAIS (Francisco) - Catálogo dos Manuscritos da Biblioteca Geral da Universidade de Coimbra relativos ao Brasil. Coimbra, 1941. (Sumaria documentes).

CV: - OLIVEIRA (Ecuardo Freire de) - Elementos para a História do Municipio de Lisboa. Tomo V. Lx.". 1891, e tomo .VI, Lx.", 1893.

- FRESTAGE (Edgar) - O Conselho de Estado. Separata do. Arquivo Histórico Português. - V. em Fontés Diplomáticas Manuscritas [B.), b), 2)], Consulta do Conselho de Estado (CXXII).

EVI - PRESTAGE (Edgar) - O Testamento da Senhora D. Maria, filha de El-Rei D. João IV, in Revista de História, vol. I, Lx." 1912.

- PRESTAGE (Edgar) - Três consultas do Conselho da Fazenda de 1656 e 1657, in Revista de História, vol. 9. ${ }^{\circ}$ Lx.", 1920 . - Já cit. na Bibliografia (L).

CVII - RIBEIRO (João Pedro) - Indice Cronológico. Tomo I a V. Lx. 1805-1820.

CVIII - SARAIVA (J. Mendes da Cunla) - Companhias Gerais de Comércio e Navegaçáo para o Brasil - I - Companbia. Geral do Grão Pará e. Maranhão. Lx.". (Documentos transcritos a p. 141).

CIX - SILVA (Antonio Deilgado da) - Collecção de Legislação. Portuguesa desde a ultima compilação das Ordenaçōes. - Legislação de 1791 a 1801. Lx. ${ }^{2}, 1826$.

CX - SILVA (José Justino de Andrade e) - Collecção Chronologica da Legislação Portuguesa. $\mathrm{Lx}^{2}, 11$ vols. (o último incompleto).

CXI - SILVA (Joseph de Seabra da) - Colleç̧ão das Provas que forão citadas na Parte Primeira, e Segunda da Dedução Chronologica, e Analytica... Lx: 1768.

CXII - SOUSA (D. Antonio Caetano de) - Provas da Historia Genealogica da Casa Real Portuguesa. Tomo. IV, $\mathrm{Lx}^{\mathrm{a}}, 1745$.

CXIII - TOMAZ (Manuel Fernandes) - Repertório Geral ou Indice Alphabetico das Leis . Extravagantes do Reino de Portugual. Vol, I, Coimbra, 1815.

CXIV - VALLE (Joaguim Rafael do) - Classificação Geral da Legislação Pottuguesa desde a publicação do Codigo Philipino até á data... Lx.". 1841.

- VASCONCELOS (Frazáo de) - A Marinha da Corôa no tempo dos Felipes, in Congresso do Mundo Portuguès - Publicações, vol. VI. (Transcreve documentos). - Já cit. na Bibliografia (LXIV).

CXV - VIDAL (Frederico Gavazzo Perry) - Interêsse que a El-Rei D. Pedro II merecen a Capitania de Pernambuco, in Congresso do Mundo Português. - Publicaçöes, vol. X, Lx. a, 1940. (Transcreve documentos).

\section{2) Mansucritas}

- A.H.C.: a) Bahia - Papéis avulsos; b) Rio de Janeiro - Papéis avulsos; c) L.0 $2 .^{\circ}$ de Consultas Mixtas.

CXVI - Alphabeto das Resoluçóes do Consello da Fazenda, Decretos e alvarás que os Reis de Portugal passaram sabre a administraçáo da sura Real Fazenda, in B.N. - Cod: 178 da Coleção Pombalina.

CXVII - Colecção de Cortes, n. ${ }^{\circ}$, in A.C. - Cod. 407-A.

CXVIII - Coleccáo de Cortes, n.o 11, in A.C. - Cod. 483-A.

CXIX - Colecgão de Cortes, n. 18 , in A.C. - Cod. 582-A.

CXX - Colleçáo de Legislação de Trigoso, vols. 8.० (1642-1656) e $9 .^{\circ}$ (16571682), in A.C. - Cods. 11.2.8. e 11.2.9.

CXXI - Consignações que váo nos almoxarifados, Alfandegas e Tesoureiros deste Reino, in B.E. - Cod. CXIII/2-28.

CXXII - Consulta do Conselho de Estado de 23 de novembro de 1656, in B.N. Cod. 738 da Coleção Pombalina. - (Publicada por Edgar Prestage, no Áchivo Kitistórico Português, vol. XI, e em separata. Mas nāo conse- 
gimos encontrar nem aquêle vol. do Archivo, que parece não ter chegado a sair, nem a separata, que não existe nas Bibliotecas Püblicas de Lisboa).

CXXIII - Consulta do Conselho de Guerra sçbre abater bandeiras da frota..., in B.A. - Cod. 51-VIl-43, fls. 130-138.

CXXIV - Consulta sôbre a queixa...., in B.A. - Cod. 50-V-35, fls. 131-147.

CXXV - Correspondência, in B.N. - Cods. 160 a 163 da Coleção Pombalina.

CXXVI - Côrtes, in B.N. - Cod. 275 do Fundo Geral.

CXXVII - Edital da Companhia Geral do Estado do Brasil, in B. A. - Cod. 5-III-2, a. 55 .

CXXVIII - Leis, in B.N. - Cod. 472 da Coleção Pombalina.

CXXIX - Leis, in B. N. - Cod. 526 da Coleção Pombalina.

CXXX - MACEDO (Antonio de Sousa de) - Razóes por que parece que - não convem à Inglaterra navegarem os seus navios para o Brasil, in B.A. - Cod. 51. V -29 , fl. 232 v. a 233 v.

CXXXI - Manuscritos da Livraria do Santo Oficio, in T.T. - Cod. 1458.

CXXXII - Mapa da Carga embarcada para Lisboa..., in B.E. - Cod. $\mathrm{CXVI} / 2-15$, n. ${ }^{\circ} 4$.

CXXXIII - Memorial de Bento Correa de Sousa Coutinho a El-Rei sôbre as razóes que the parecem convenientes para o aumento da Fazenda Real, se El-Rei mandar fabricar Fragatas nas Ribeiras de Angra dos Reis e mais circumvizinhas do Rio de Janeiro; in B.E. - Cod. CXVI/2-13. п. 26.

CXXXIV - Miscelànea, in B.N. - Cod. 495 da Coleção Pombalina.

CXXXV - Miscelânea, in B.N. - Cod. 738 da Coleção Pombalina.

CXXXVI - Papeis dos Jesuitas, in T.T. - 1. Caixa.

CXXXVII — Parecer do Mordomo-mor D. João da Silva, dado à Rainha in B.A. - Cod. $51-V-41$, fl. 48.

CXXXVIII - Ningtuem pode duvidar..., in B.E. - Cod. CV/1-17, p. 207.

CXXXIX - A Nova Companhia do Comércio que intentem fazer os homens de negócio da praça de Lisboa..., in B. N., Cod. 495 da Coleçã̃o Pombalina, fls. 45-48.

CXL - Rápida Descrição Histórica da Alfândega das Sete Cazas, in B.N. - Cod. 235 do Fundo Geral. 


\section{DOCLMENTOS}

1) - 1646 - janeiro - 29 - Dec. para o Conselho Ultramarino consultar sôbre alguns meios de segurar a navegação do Brasil - ou obrigando os navios mercantes a andar artilhados, ou fretando em Hamburgo 10 naus de guerra para dar comboio aos barcos de comércio. - A.C. - Cod. 582-A. (Col. de Córtes, n. ${ }^{\circ} 18$, in tomo $10^{\circ}$ ). - Sumário em José Justino de Andrade e Silva. Coleção Cronológica da Legislação Portuguêsa, 2." Série (1640 1647). p. 300.

2) - 1646 - setembro - 13 - "Copia de huma carta de S. Mag. ${ }^{\text {e }}$ em que declara 0 d. ${ }^{\circ}$ Sr. que o rendim. ${ }^{\text {to }}$ do subsidio do vinho foi aplicado p." sustento do Prezidio". - A.H.C. - R. de Jan. ${ }^{\circ}$ - Doct. ${ }^{\circ}$, n. $^{\circ} 6083$.

3) - 1648 - março - 15 - Alv. proibindo que se façam, importem, neni (passados 3 anos) naveguem navios de menos de 350 toneladas e 16 peças de calibre 8. - Indicação em alv. de 25-1-1649, in B.N., Res. 100 A. (Leis várias do século XVI): em Joaquim Rafael do Valle, Classificação Geral da Legislação Portuguêsa, p. 233.

4) $-1648-$ abril $-2-O$ mesmo do antecedente. - No referido Valle, ob. e p. cits.

5) - 1648 - maio - 14 - Prov. real concedendo licença a um navio inglês para levar bacalhau da Terra Nova à Bahia. - A.H.C. - Bahia Papéis avulsos - 1649 - maio - 18 .

6) - 1648 - agôsto - 21 - Sôbre se tirar devassa dos capitães da nau Candelaria e do galeão Santo Antônio se haverem apartado do galeão São Lourenço, sua Capitània. - A.H.C. - L. 2..$^{\circ}$ de Consultas Mixtas (16461652), fl. $128 \mathrm{~V}$.

7) - 1648 - outubro - 15 - Consulta do Conselho Ultramarino: por carta de 12-2-1648 o Rei mandara ao governador do Brasil que consultasse os oficiais da Fazenda sôbre se o sal deveria continuar a navegar-se por conta da Fazenda real, arrendar-se ou tornar-se livre a sua navegação, mediante um impósto. Os moradores do Brasil preferem a última modalidade e oferecem de impósto 2.000 rs. em moio; não podendo ser assim, que continui estanco real, levando-o, porém, todos os barcos: em nenhuma maneira se arrende. Ao Conselho parece que continui como dantes, levando-o todos os navios. - L. $2^{\circ}$ de Consultas Mixtas (1646-1652), fl. $138 \mathrm{~V}$.

8) - 1648 - novembro - 20 - Roque de Barros Rêgo, governador de Cabo Verde, dá conta da briga que teve na viagem com uma nau holandesa. - A.H.C. - L. 2..$^{\circ}$ de Consultas Mixtas (1646-1652), f1. 145 V.

9) - 1648 - novembro - 26 - Consulta do Conselho Ultramarino sôbre dever-se publicar em forma de lei a ordem real dada por decreto ao Conselho para, por editais, se proibir a navegação para as conquistas; salvo Ihas e Africa, em caravelas, e dever-se conceder prazo para os donos das caravelas substituirem estas. - A.H.C. - L. $0^{\circ}$ de Consultas Mixats (16463652), fl. $146 \mathrm{~V}$.

10) - 1648 - novembro - 27 - "Tenho nomeado governador para o Brasil. que partirá brevemente com 4 navios, para virem dando combôio a Capitánia e almiranta da armada e trarão a fazenda que chegou dà India àquēle Estado" (Despacho real em consulta). - A.H.C. - L. $.^{\circ} .^{\circ}$ de Consultas Mixtas (1646-1652), fls. 146. 
11) - 1648 - novembro - 28 - A Cāmara do Rio de Janeiro queixäse de faita de sal. - A.H.C. - L. $0^{\circ} .^{\circ}$ de Consultas Mixtas (1646-1652), fls. .150 .

12) - 1649 - janeiro - 25 - Alv, reduzindo ao porte minimo de 250 toneladas e ao armamento minimo de 16 peças de calibre 8 a 5 a exigéncia expressa no alvará de 15-3-1648, permitindo que se façam navios de menores tonelagem e armamento mediante licença do Conselho da Fazenda, e fazendo várias mercês aos donos e mestres de barcos de porte superior a 350 toneladas. - B.N. - Res. 100 A. (Leis várias do séc. XVII).

13) - 1649 - março - 8 - Instituição da Companhia Geral para o Estado do Brasil - Coleçāo cronológica de legislação portuguêsa, compilada e anotada por José Justino de Andrade e Silva - Segunda Série - 1648-1656 Lisboa 1856 - De páginas 31 a 41. - B.N., Res. 98-A (Leis várias), N. ${ }^{\circ} 1$. - B.N., Cod. 526 da Coleção Pombalina, fls. 23. - A.C., Cod 11.2.8 (Coleção de Legislação Trigoso, vol. 8..$^{\circ} 1642$ a 1656), n.. 38.

14 - 1649 - março - 16 - Edital da Companhia Geral do Estado do Brasil - B.A. - Cod. 54-III-2, n. 55.

15) -1649 - maio - 18 - Consulta do Conselho Ultramarino: "João Miles pede licença para mandar um navio ingless de 200 toneladas. com gente inglêsa, da Terra Nova em direitura à Bahia, com carga de bacalhau". Tendo sido a provisão concedendo licença para tal ao impetrante passada um ano antes, ao Conselho parece já nčo poder sêr utilizada, em vista do privilégio da Junta do novo comércio. - Despacho do Rei: "Como parece". A.H.C. - Bahia - Papéis avulsos - 1649.

16) - 1649 - junho - 10 - Em carta do Cardeal Paloto: "Vejo com grande maravilha o contrato que a gente de negocio tem feito para defender dos Corsarios as frotas da India, E Brasil, pois desta resoluçăo não posso senão inferir (mas praza a Deoś gue eu me engane) a total destruição desse Reyno e Rey delle, abrindose a porta adãnos lacrimaueis de nossa santa fée, E religião catholica, e á nobreza do mesmo Reyno ficar sogeita hum dia a Christãos nouos" - B.E., Cod. CV/2-9, p. 332.

- 17) - 1649 - junho - 26 - "Do Conselho Ultramarino — Sôbre a falta que ha de gente na praça da Bahia e sustento para ela". - A.H.C. - Bahia - Papéis avulsos - 1649.

18) - 1649 - julho - 23 - Carta da Câmara do Rio de Janeiro sôbre a falta de sal e pedindo a proibição da aguardente da terra - A.H.C. Rio de Janeiro - Papéis avulsos - 1649.

19) - 1649 - julho - 24 - Pareceres do Conselho de Guerra, do Conde de Odemira e de outros sôbre a forma em que se há-de haver a Arnada da Companhia no abater das bandeiras quando se encontre com a Armada Real ou as naus da India. - B.A. - Cod. 51-VII-43, fls. 130-138. - Sumário em Carlos Alberto Ferreira. Subsídios para a bistória do Brasil na época do D. João IV, in Congresso do Mundo Português - Publicações - Ix. 1940, vol...IX.

20 - 1649 - agôsto - 11 e 31 - Consultas do Conselho Ultramarino alegando razōes dos moradores do Brasil para se não executar o decreto que manda proibir o vinho de mel, aguardente da terra e a cachaça. - Despacho do Rei mantendo o decreto. - A.H.C. - L..$^{\circ}$ de Consultas Mixtas (16461652), fls. 181 e 188 .

21) - 1649 - setembro - 13 - Provisão real insistindo no cumprimento da ordem de 21-2-1647, proibindo no Brasil o vinho do mel, aguardente $e$ cachaça, em virtude de reclamação da Cia. Geral do Comércio. - A.H.C. R." de Jan." - Doct. ${ }^{\circ}$. $^{\circ} 723$. 
22) - 1649 - setembro - 13 - Decreto com o Regimento que as armadas da Companhia Geral devem seguir estando surtas ou encontrando-se no mar com as armadas reais. - Transcrito in extenso na cópia do Regimento de 1655 - abril -12 - (V. doc. n. $^{\circ} 89$ ).

23) - 1649 - setembro - 23 - A Companhia do Comércio não paga direitos dos vinhos que carrega na Ilha da Madeira, ou para si, ou para o contrato. - Liv. 2 dos Decretos, fls. 116 V. - B.N. - Cod. 178 da Coleçâo Pombalina (Alfabeto das Resoluçöes do Conselho da Fazenda), fl. 72 V.

24) - 1649 - outubro - Consulta do Conselho Ultramarino com carta do Governador do Brasil e despacho do Rei mandando voltar juntas do Brasil a Armada Real, a da Companhia e as naus da India aportadas. - A.H.C. L. 2." de Consultas Mixtas (1648-1652), fi. $197 \mathrm{~V}$.

25) - 1649 - novembro - 4 - "Relação e Lista dos nomes das Naus e das toneladas que cada uma leva e das peças e Capitães: - São Paulo, capitânea. Toneladas 840, Capitáo Ralael Coelho. - São Pedro, almirante, Ton. 480. Capitão João Faleirc. - São Pedro de Lisboa, ton. 480, peças 34, Capitão Vitório Regalo. - São Teodósio, Ton. 450, peças 30, Capitão Nicolau de Sequeira. - São João, Ton. 440, peças 30, Capitão Antônio Temudo. - Santa Luzia, Ton. 360. peças 30, Capitão Bernardo Ramires. - São Francisco. Ton. 350, peças 30, Capitão António de Abreu de Freitas. - Conceição. Ton. 300, peças 24, Capitão Francisco Barroso. - Jesús Maria José, Ton. 250, peças 26, Capitão Domingos da Silva. - Santo Antônio de Porte, Ton. 250, peças 20. Capitão João dả Rocha Leão. - Santo Antônio de Pádua, Ton. 400, peças 26, Capitão António Fernandes da Costa. - Sáo Ciprião, Ton. 400. peças 28. Capitão Marçal Nunes da Costa. - Benção, Ton. 300. peças 24. Capitão Francisco Moi Fereira. - Frei Simões, Ton. 300, peças 28, Capitão Antônio Varregoro. - Tomaz e Lusia, Ton. 300, peças 26, Capitão Antōnio de Mendonça. - Talber, Ton. 300, peças 28, Capitão Simão Pereira de Saa. - São Pedro Grande, Ton. 450, peças 32, Capitão Pedro Teles. - . Nossa Senhora da Graça, Ton. 300, peças 26. Capitáo Jaques Bael. - Saiu esta armada pela barra fora em 4 de novembro de 1649 e foram 66 embarcações e as 50 bem artilhadas". - B.A. - Cod. 52-X-2, n. ${ }^{\circ} 85$.

26 - 1650 - fevereiro - 4 - Resolução do Rei em consulta do Conselho da Fazenda indeferindo o pedido da Companhia para não pagar direitos do cobre importado para apresto de suas armadas. - Cons. de ptes, de $1647_{\text {t }}$ fl. 156 V. - B.N. - Cod. 178 da Col. Pombalina (Alfabeto das Resoluçóes do Corisetho da Fazenda), fl. 63.

27) - 1650 - fevereiro - 18 - Da resolução, que, por assento, se tomou na Bahia, de a Armada da Companhia não vir ao Rio de Janeiro resultou desunir-se esta frota da da Bahia e ser a primeira destroçada por navios holandeses. - A.H.C. - L. 2. de Consultas Mixtas (1646-1652), fl. 240 .

28) - 1650 - março - 10 - Consulta do Conselho da Fazenda sôbre vinhos no Brasil, seu preço e não querer a Companhai pagar direitos - Cons. de ptes. de 1647, fl. 161. - B.N. - Cod. 178 da Col. Pombalina (Alfabeto das Resolnçốes do Cons. da Faz.), fl. 63.

29) - 1650 - março - 10 - Consulta do Conselho da Fazenda sôbre - pau brasil e a interpretação do cap. 25 da Instituição da Companhia. Cons. de ptes. de 164\%, fl. 163 V. - B.N. - Cod. 178 da Col. Pombalina (Alfabeto das Resoluçôes do Conselho da Fazenda), fl. 63.

30) - 1650 - março - 20 - Carta do Conde de Castelo Melhor, governador do Brasil, para a Cámara do Rio de Janeiro, sōbre os navios da Companhia que nesta ocasiáo foram. - Catálogo dos Mss. da Bibl. Nacional do Rio de laneiro, in Annaes da Biblioteca Nacional do Rio de Janeiro, Vol. IV (1877-1888), p. 129, fl. 19. 
31) - 1650 - abril - 28 - Carta do Governador Conde de Castelo Melhor a $D$. João $N$, queixando-se de não querer a Cia. pagar pelos vinhos idos do Reino mais do que os mesmos direitos que paga pelos da Madeira (3.000 e tantos réis). - Tem à margem o seguinte Despacho Real: "Veyasse e consultesse no Cons. ${ }^{\circ}$ Ultramarino em Lisboa a 30 de $\mathrm{M}^{\text {co }}$ de 1651 - $\left(\mathrm{R}_{\mathrm{u}}\right.$ brica do Rei D. João IV)". - A.H.C. - Bahia - Papeis avulsos - $165 i$.

32) - 1650 - maio - 16 - "Copia da carta dos officiaes da Camr." da Capitania de Spirito Santo. - Dá conta do mizerauel estado em que se acha por falta de comercio, que tem de ser menos com a criação da noua companhia e $n^{\text {des }}$ (necessidades) que padecem por falta de tudo e de sal, e outros particulares". - A.H.C. - Bahia - Papéis avulsos - 1650.

33) - 1650 - maio - 17 - Cartas do Governador do Brasil, para os llheus, sôbre mantimentos da armada da Companhia, - Catálogo dos Mss. da Bibl. Nac. do Rio de Janeiro, in Annaes, vol. IV p. 58, fl. 19.

34) - 1650 - maio - 18 - Carta do Provedór da Fazenda do Rio de Janeiro para o Rei, sobbre falta de sal, apesar de terem chegado 2 barcos, um da Companhia e um mercante, com êle, e falta de navios para levarem os açúcares. - A.H.C. - Rio de Jan. - Papéis avulsos - 1650.

35) - 1650 - junho - 30 - Carta do Provedor da Fazenda do Rio de Janeiro para $\circ$ Rei sóbre não terem os mestres dos 3 navios da Companhia, que deram combôio à frota, querido pagar direitos dos açúcares e drogas que levaram, e perguntando como proceder em tal caso. - A.H.C. - Rio de Jan. - Papéis avulsos - 1650.

36) - 1650 - julbo - 10 - Carta do Governador do Rio de Janeiro pedindo que a Companhia mande vinho e sal em quantidades suficientes. A.H.C. - Rio de Jan. - Papéis avulsos - 1650 .

37) - 1650 - julho - 19 - Carta do Governador do Brasil contando como introduziu a Companhia, a repugnância do povo sôbre se năo tirarem as vendagens dos preços por que a Companhia se obrigou a vender os 4 gêneros e como se aquietou ao saber as razōes do caso. - A.H.C. - L. ${ }^{\circ}$. $^{\circ}$ de Consultas Mixtas (1646-1652), fl. 244.

38) - 1650 - julho - 21 - Sôbre o queescrevem os oficiais da Câ. mara da Bahia acêrca de os administradores da Companhia venderam os 4 gêneros do seu estanco mais caros do que os preços das taxas, além de os só venderem por grosso, para não pagar as vendagens. - Tem despacho real de 9-9-1650 mandando que a Companhia não altere os preços contratados e paque ela os salários dos vendedores. - A.H.C. - L. $2 .^{\circ}$ de Consultas Mixtas (1646-1652), fl. 243.

39) - 1650 - agôsto - 30 - Consulta da Companhia Geral sôbre não ter o Conde de Castelmelhor observado o regimento da armada da $\mathrm{Ci}^{2}$., na parte em que mandava que, chegada aquela à Bahia, e descarregados os gêneros do estanque, logo seguisse para o Rio de Janeiro, donde, comboiando os navios mercantes que ai estavam, voltaria à Bahia, partindo depois daí, com a Armada Real para o Reino. dando combôio a tôda a frota dos açúcares. Em vez de tal, as armadas ficaram na Bahia, donde tornaram ao Reino, sem 3 návios que, sós, haviam ido ao Rio, donde voltaram, à-parte, para a Metrópole, com 20 navios de comércio, em grave risco pela förça de inimigos que havia cêrca das Ilhas e da Costa Portuguêsa. - Com resolução do Rei concordando, cópia do decreto que mandara cuvir a $\mathrm{Ci}^{\mathrm{n}}$., outra consulta (de 26-9-1650) da $\mathrm{Ci}^{\mathrm{s}}$. sôbre prisão dos capitães das 5 naus inglésas incorporadas na armada que vinha do Brasil, deferimento real e cópia dos capitulos 11 e 19 do regimento da armada. - A.H.C. - Bahia - Papéis avulsos -- 1650.

40) -1650 - setembro $-6-" \bar{A}$ Companhia quis ter privilégio sôbre - lealdamento pelo cap. 41 do contrato querendo que todos lealdassem: resolveu-se que cortia o pleito e que a sentença que se desse se seguisse". - L." 
3 das Cons. do Ser., fl. 29. - B.N. - Cod. 178 da Col. Pombalina (Alfabeto clas Resolucoōes do Conseino da Fazenaia), fl. 63.

41) - 1650 - setembro - 9 - Despacho real mandando que se guarde o assentado com a Companhia, lançado sóbre Consulta do Conselho Ultramarino apoiando as queixas do Governador do Brasil e da Cámara da Bahia contra a Companhia por são querer pagar direitos dos vinhos. - Em consulta de 19-5-1651 o Conselho replica que o Cap. 22 do assento da Companhia é confuso, e a matéria se deve considerar de novo. - A.H.C. - L. $20^{\circ}$ de Consultas Mixtas, fl. 242 V. e 293 V.

42) - 1650 - outubro - 12 - Consulta do Conselho Ultramarino sōbre näo querer a Companhia, no Rio de Janeiro, despachar os açúcares. - A.H.C. - L." 2. ${ }^{\circ}$ de Cons. Mixtas, fl. 252 V.

43) - 1650 - cutubro - 12 - Sôbre falta de sal no Rio de Janeiro. - Tbidem, fl. 253.

$44)$ - 1650 - outubro - 20 - Carta do Governador do Brasil dizendo que a frota partida da Bahia a 24 de setembro de 1650 contava, incluindo a Armada Reai, a da Companhia e os navios mercantes, 70 unidades. - A.H.C. - Bahia - Pzpéis avulsos - Consulta de 1651 - jan. ${ }^{\circ}$ - 25.

45) - 1650 - dezembro - 19 - Consulta do Conselho Ultramarino sôbre dever-se mandar remediar a falta de sal e de vinhos no Rio. - A.H.C. - Rio de Jan - Papéis avulsos - 1650.

46) - 1651 - janeiro -26 - Do Conselho Ultramarino - Com as cartas e provisões, passadas; em favor dos Administradores da Companhia Geral do Comercio do Brasil, contra os officiaes da Camara da Bahia e vay o decreto por que se passarão". - A.H.C. - Bahia - Papéis avulsos 1651 .

47) - 1651 - fevereiro - 27 - Resolução do Conselho da Fazenda: pode a Companhia nomear um feitor para a parte que se fêz de novo na Alfandega desta cidade e outro para a Casa da India, para verem os bilhetes e se fica pago o comboio e avaria. - L. 3 das Cons. do Serv. fl. 36. A.H.C. - Cod. 178 da Col. Pombalina (Alfabeto das Resoluções do Consetho da Fazenda), 1163.

48) - 1651 - março - 3 - Consulta do Conselho Uiltramarino sôbre exigir-se à Comparihia o pagamento do pau Brasil já cortado por conta da Fazenda, que a Companhia requereu se lhe entregasse, conforme ao seti assento. - A.H.C. - Bahia - Papéis avulsos - 1651.

49) - 1651 - março - 31 - Do Conselho Lltramarino lembrasse a S. Mag eì quanto convem tratar-se da conservação do Estado do Brasil E o de que neccssita para isso". (Queixa-se da falta de frotas, demoras deias: caréncia de géneros estanques no Brasil; imposiçóes nos açúcares. Que se deizem ir fora da frotá navios de fôrça ou ligeiros). - A.H.C. - Bahia - Panéis avalsos 1651 .

$$
\begin{aligned}
& \text { 50) - } 1651 \text { - Maio }-2- \\
& \text { S. Mag. }{ }^{\text {de }} \text { a Cone t." convinha socorresse o brasil e resposta que a } \\
& \text { Ella derão os Ministros da Junta do nosso Comerçio pl. sua } \\
& \text { Const." inclusa. }
\end{aligned}
$$

Havendo Este Cons. ${ }^{\circ}$ feito a V. Mag. ${ }^{\text {do }}$ em 31 do mez p. do a Const." inciusa sobre o Estado do Brasil $E$ o que mais convinha de prez. ${ }^{\text {te }}$ a sua deffensa $E$ conservação, aug. "." (aumentos) da faz. ${ }^{2}$ Real continuação $E$ segurança do Comercio prepetuidade $E$ avanços da Junta delle Referindo bastatemente as cunzas que havia p." fazer esta lembrança porque sendo patentes os danos hera s. ${ }^{r *}$ (necessário) apontar o remedio. Pedio este Cons. ${ }^{\circ}$ per conclusāo da ditta 
Const." que V. Mag. ${ }^{\text {Ae }}$ mandasse ouvir os Deputados da junta com Ministros de sua Real faz." E estado para que tratassem do que fosse mais conveniente em neg. (negócio) de tanta importancia. Teve a. Junta $\mathrm{Vt}^{\mathrm{a}}$ (vista) da ditta Const." E respondeo (com a que veo $E$ torna cô Ella). Escusandose da ditta conferencia, cousa não esperada do seu zello porque serrar as orelhas á razão $E$ não querer conferir sobre os dannos que o tempo tem mostrado $E$ os meios prodenciais do reparo cielles. Estranhão os vassalos nos Reis Razão mais obrigatoria a que os Reis o nāo permitirão aos Vassalos.

$\mathrm{S} .^{n \pi}$. Estas materias não se tratam por papel e tinta seño ouvindo, côferindo $E$ resolvendo o que parecer mais acertado ao bem $p .{ }^{\circ \circ}$ (público) que para ajustam. ${ }^{\text {tos }}$ athe cõ os Inimigcs se vem a falla: se as razôes da Cons. ${ }^{a}$ são. leves com poucas palavras the poderão dar satisfação os Deputados da Junta $E$ não ha que temer na Conferencia em que se não pretende fazer cargos a ninguem inda que os tiverão senão apurar os acertos de boin governo pl. ${ }^{\circ}$ voto dos mais $p^{2}$. satisfação de queixas $E$ mayor utilidade da Junta, e se tem fundam. ${ }^{\circ}$

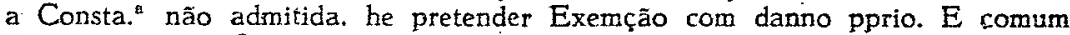
$\mathrm{E}$ asy torna o Cons. ${ }^{\circ}$ a pedir a $\mathrm{V}$. Mag. ${ }^{\mathrm{d}}$, com a sumissão devida mande fazer conferencia $\mathrm{pl}^{\circ}{ }^{\circ}$ Ministros que for servido $\mathrm{pl.}{ }^{\mathrm{a}}$ grande importança da matr. (matéria) ou a mande ver p. ${ }^{108}$. Procu. ${ }^{\text {or }}$ 's da sua Coroa $E$ - faz." que assitirão ao contratado cõ a Comp. ${ }^{a}$ como se ve da puisão. (provisão) de sua confirmação.

Mas p." que V. Mag. do veja desde logo q. ${ }^{\text {to }}$ tem fundam. ${ }^{\text {tn }}$ se responde ao que por obrigação precisa representou este Cons. e enç. ${ }^{\mathbf{t a}}$ cousas não dá cumprim. ${ }^{\text {to }}$ a Companhia ao prometido fazemos a demonstração seguinté.

Primeiram. ${ }^{l e}$ não tem a Companhia a metade da armada que prometeo porque a puisão (orovisão) pcrque foi confirmado o seu Contrato he de dés de Março de 649. E são passados athe hoje mais de dous annos sem. se fazer nem se mandar ao Brasil mais que hua so Esquadra de desoito vellas das quaes $\mathrm{m}^{\text {tas }}$ herão fretadas que já hoje faltão sendo obrigados a fazer duas Esquadras de trinta e seis vellas $\mathrm{E}$. mandallas no dito termo de dous annos como consta do principio de sua instituição na $p .^{\text {r* }}$ (primeira) Lauda, E melhor da provisão de V. Mag. ${ }^{\text {de }}$ que vay no fim que diz que andarão no mar trinta E seis naos de guerra em duas Esquadras, na forma de sua condiçāo, que vão a venhão dando guarda, e comboy ás embarcaçöes, e faz. as (f́azendas) do Brasil em utilidade, e bem comu de todos os vassalos, e dr. ${ }^{\text {tos }}$ (direitos) das Alfandegas.

De se não dar cumprim. ${ }^{\text {to }}$ a esta principal obrigação nascem os danos seg. $^{\text {ter }}$, que no Brasil faltão os 18 Navios de querra que enq. ${ }^{\text {to }}$ estão nelle emparão aq. ". (aquê̂le) estado e enfreão o inimigo, e aqui os outros desoito de segd." (segunda) Esquadra, tem a nesma utilidade, p. ${ }^{2}$ a defensa deste Reirio, e em particular deste Porto e Barra; $O$ Comerçio não logra o benef (benefício) de empregar mais vezes seu cabedal; As alfandegas perdem os drt. ${ }^{\circ}$, e a Junta seus interesses, Utilidades que todas forão causa, e se considerarão $p{ }^{A}$ se haverem de admitir os estanques, drt. ${ }^{\text {s }}$ novos nos açúcares, e mais cousas pedidas, e consedidas, afim de poderem sustentar as duas Armadas sempre vivas.

Tem mais o dano de faltarem no Estado do Brasil os mantimt. ${ }^{o s}$ dos estanques, que com a dilação das Armadas, näo há mais que P." os ricos, $\mathrm{E}$ os que ha são de peior qualid. E se comprăo de seg. ${ }^{\text {dn }}$ mâo a preços excessivos padecendo tambern os moradores do Brasil o fazeremse seus açucares de tão roim q. ${ }^{d e}$ (qualidade) por vallor que valem m. ${ }^{\text {to }}$ menos la $E$ cá $E$ tambem padeçe $m .{ }^{\text {to }}$ a mercançia que tratando so no que não he Estanque sem os empregar $E$ retorno delle m. ${ }^{: 0}$ retardados dano comu do Reino, da Fazd." Real ras Alf. ${ }^{2 s}$ (Aifândegas), E da mesma Companhia.

E porque a tenção do Cons. ${ }^{\circ}$ hera conforme sua obrigação Evitar estes danos $\mathrm{E}$ prevenillos p. ${ }^{\mathrm{a}}$ o futuro apontou na sua Const." os meos convenientes p. $^{2}$ se socorrer o Brasil por via da mesma Companhia se o quizesse fazer por 
Eiles, ou por os de V. Mag. ${ }^{\text {** }}$ aprouandose v. $^{\text {to }}$ (visto) estar o Brasil de prez to despptaido. (desprovido).

E a satisfaçào qué a Junta dá $E$ prouim. ${ }^{\text {tos }}$ que aponta cõ o sobjunto a sua const:" de 28 navios Em que entram cinco que não tem partido não he bastante como se mostra Evidentem. ${ }^{\text {te }}$ p. $^{10}$ que diz no seu papel porque nos dows annos de 647. E $648 \mathrm{em}$ que refere se perderão duzt as (duzentas) (1): $\mathrm{E}$ vinte Embarcaçōes não forão senão duz. ${ }^{\text {t*s }} \mathrm{E}$ quarenta e nove $\mathrm{E}$ destas no anno de 647 , se perderão cento e oito $E$ no de 648 . se perderão cento $E$ quarenta e buma como cōsta do papel junto com os nomes dos mestres $E$ navios tirado dos L." (bivros) do seguro cō o que ajuntando as que vierão a salvm." nos ditos douis amnos que são $\mathrm{m}^{\text {tas }}$ virião a hir $p^{\text {" }} \circ$ Brasil nos mesmos dous annos (quatro (2) mais a menos) mais de trez. ${ }^{\text {tas }}$ Embarcações do que se infere que hindo p." 0 Brasil repartidam. ${ }^{\text {te }}$ p. $^{20}$ dittos dous annos cento $e$ cing. "* E cinq. to Embarcaçōes em cada hu, não he provim. ${ }^{\text {to }}$ p." Elle as vinte outo que em mais de anno vem a mandar a Com." que mais tempo vai de q. $^{\circ}$ comessou este provim ${ }^{\text {to }}$ ao em que la poderã chegar a armada sendo que senão faz conciderą̧ão de que assi como de trz. ${ }^{\text {tex }}$ se perderão as cinco p. ${ }^{\text {tos, }}$, hindo as vinte oito do Rol na mesma forma podem tambem ter a mesma fortuna o que Ds. (Deus) nào premita $E$ bem se deixa ver a $n .^{d e}$ (necessidade) que sentírá o Brasil có falta semelhante.

E como as cousas de mar são tão incertas e os sucessos de armadas grandes e formadas de novo tăo varics, podendo a que hade partir ter hú impedm.to de temporal ou de Enemigos nesta barra na viagem ou nas Costas daq. ${ }^{1 .}$ Estado se acrescenta mt. ${ }^{\circ}$ mais não so a ditta $a^{\text {de }}$ (necessidade) mas a concideração de mayor perigo.

Rasōes que todas justificão Evidentem. ${ }^{\text {tc }}$ as causas que moverão ao Cons. a fazer sua obrigação com a ditta Cnst.. em a q. ${ }^{1}$ (quai) por não parecer que fazia cargo deixou de dizer que da p. ${ }^{\text {to }}$ de V. Mag. ${ }^{\text {de }}$ estava satisfeito a tudo prometido $E$ contratado $E$ घão se referio que da $p .^{\text {te }}$ da Comp. ${ }^{a}$ se estava provendo como antes de sua instituição sem comboy. (levando dir. ${ }^{\cos }{ }^{*}$ como se 0 fizera na forma contratada) tendo os vassalos o perigo sem liberdade no Comercio E a Junta o pri. to (proveito) e padecendo a faz.. de V. Mag. ${ }^{\text {co a }}$ despesa grande da detença de armada Real, a pedim. ${ }^{\text {to }}$ da Companhia sem pedir 0 custo antes premitindo à Companhia o dirt. ${ }^{\circ}$ dos açucares fabricados antes do contratado com Ella e carregados em a ditta armada Real, E porque esta Matr." pede toda a brevidade $E$ pareceu ao Cons. que este papel diz o que basta sendo V. Mag. ${ }^{\text {de }}$ servido que se mostre mais particularm. ${ }^{\text {to }}$ a pouca sustançia do da Comp." se mostrará respondendo a tudo, que tudo delle he como a sahida que dá à sua obrigaçāo confessando que ainda quea tem de fazer trinta $E$ seis navios satisfaz com desoito por valerem mais que os trinta $E$ seis $E$ serem formidaveis ao Inimigo, não conçiderando os danos já apontados de faltarem cō hua Esquadra mayor no futuro $E$ que sem duas não pode haver soccorros e tp. ${ }^{\circ}$ (termpo) do dir. ${ }^{\text {to }}$ nas Alf. mantim. ${ }^{\text {tos }}$ de boa q. ${ }^{\text {do }}$ (qualidade), nem avanços no Cabedal da Comp. V. Mag. mandará o g." for servido. Em Lx." a 2 de Mayo de 1651. O Conde de Odemira - VOs. (Vasconcelos - figr.", (Figueira) - Moura Pr." (Pereira).

Tem à margem o seguinte despacho Real:

Agradeço m. ${ }^{\circ 0}$ ao Cons..$^{\circ}$ Zello de meu servç. ${ }^{\circ}$ com que me faz as lembranças de que trata esta Const.". e a gue será em comp." della; mandey prouer en tudo que pareçeo conveniente, e possivel, ao estado em que a Comp." se acha, em Alcantara a 31 de Mayo de 651. - Rey:" - A.H.C. L. 2: de Consultas Mixtas, Ano de 1646-1652, fls. 290-291. V.

(1). - Erro evidente de cópia. Deve ser "tresentos", como se vê do seguimento da trase.

(2). - o que parece ler-ge. Talvez "quãto". 
51) - 1651 - maio - 19 - Carta do Governador do Brasil sôbre queixas da Câmara da Bahia contra a Companhia. - A.H.C. - Bahia Papéis avulsos - 1651.

52) - 1651 - junho - 17 - Consulta do Conseiho Ultramarino, e despacho nela, sóbre padecer falta de sal o Brasil por caréncia de navegação para ésse Estado. - A.H.C. - L. 2..$^{\circ}$ de Consultas Mixtas (1646-1652), f1. 301.

53) - 1651 - junho - 20 - Carta de Dom Luiz de Almeyda, capitão da praça do Rio de Janeiro, a El-Rei, dando conta das despesas do presidio e receitas com que se thes acode; queixando-se da Cia. por falta de barcos e de vinho. - A.H.C. - Rio de Janeiro - Doct. ${ }^{\circ} .^{\circ} 712$.

54) - 1651 - junho - 6 - Carta de Francisco da Cruz nomeado Sargento Mor do Rio de Janeiro, a El-Rei, ponderando a muita necessidade de géneros que padece $\circ$ Rio, pois em 2 anos só recebeu 5 barcos (3 da frota e 2 fora dela), e alvitrando gue, em vez das caravelas e patachos que se projeta enviar com infantaria, vão 2 ou 3 navios grandes: - A.H.C. - Rio de Janeiro - doc. n. 711 .

55) - 1651 - julho - 30 - Carta dos oficiais da Cámara do Rio de Janeiro a El-Rei, defendendo-se da acusação de culpa no caso dos navios que se perderam por se não terem juntado à esquadra na Bahia, e queixandose da Companhia e das suas opressóes. - A.H.C. - Rio de Janeiro - Papéis avulsos - 1651 .

56) - 1651 - setembro - 22 - "Do Conselho Ultramarino - Sobre o. nauio que se manda tomar no Rio de-Yanero, por hir a Elle, sem ordem da Comp." geral, E vay a prouissão com a postilha, E mais copias que se acusão". O Conselho discorda de que se dê o terço da apreensão ao denunciante, fundado na análise dos arts. 18,20 e 22 da Instituição da $\mathrm{Ci}^{\mathrm{a}}$. - $\mathrm{O}$ Rei não atende o parecer do Conselho - Incidentalmente diz que as avariás do Combôio "não as há senão de volta para este Reino" - A.H.C. - Rio de laneiro - Doc. $n .^{\circ} 717$ e 718 .

57 - 1651 - setembro - 22 - Consulta do Cons. Ultram. propondo se contrate com particular o arrendamento do subsidio do vinho no Rio - e a remessa a essa cidade de 1.000 pipas dêle (para ser vendido sómente depois do estanque da $\mathrm{Ci}^{2}$.). a menos que a $\mathrm{Ci}^{2}$. mande vinho suficiente ou tome sôbre si a paga dos 16.000 cruzados do vissidio do vinho. - A.H.C. - Rio de Janeịro - Doc. n. 720 .

58) - 1651 - outubro - 20 - "Do Conselho Ultramarino - Com o papel da Junta do nouo Comerçio em que aceita tomar sobresy, o subcidio dos vinhos do Rio de Janeiro". - A.H.C. - Rio de Janro. - docto. n. 722.

59) - 1651 - novembro - 6 - "Do Conselho Ultramarino - Com húa carta $p{ }^{i}$ o Conde Gov." do Brasil. sobre a guarda $E$ observancia do Capitulado com a Comp.* g. ${ }^{1}$ para S. Mag. assinar, sendo servido. E vay: a copia do decreto que se acusa". - A.H.C. - Bahia - Papéis avulsos 1651:

60) - 1652 - fevereiro - 20 - Companhia: sobre o seu Regimento nào compreender os mantimentos que S.M. manda para os soldados do Brasil. - Cons." com boas razōes". - L. Cons. do Serv. de 1647. - B.N. Cod. 178 da Col. Pombalina. (Alfabeto das Resoluções do Conselho da Fazenda), fl. 63 .

61) - 1652 - setembro - 12 - Petição da $\mathrm{Ci}^{\mathrm{a}}$. G. do Com., queixando-se de irem estrangeiros ao Brasil assentar casa de negócio, contra as leis do Reino. Despacho de El-Rei mandando averiguar. - A.H.C. - Bahia Papéis avulsos - 1655 - marco.

62) - 1652 - outubro - 31 - Consulta sôbre petição de 5 estrangeiros moradores em Lisboa e homens de negócio que sáo acionistas da Companhia. - A.H.C. - Bahia - Papéis avulsos - 1652. 
63) - 1652 - dezembro - 10 - Consulta do Conselho Ultramarino sôbre requerimento, do dono de um navio mercante, que vai ao Brasil, de licença para constituir até uma quarta parte da tripulação com marinheiros estrangeiros, vista a falta de nacionais. (Aparecem vários outros pedidos idênticos, en diversas datas; por via de regra, o Conselho dá parecer favorável). - A.H.C. - Bahia - Papéis avulsos - 1652.

64) - 1652 - dezembro - 16 - Consulta do Cons. Ultr. sōbre pedido de autorização para levar artilheiros estrangeiros em barco que vai ao Brasil (Observação idêntica à do número anterior). - A.H.C. - Rio de Jan. Papéis avulsos - 1652.

65) - 1653 - maio - 14 - Consulta do Conselho da Fazenda: "Companhia do Comércio, havendo noticia que tratava mal as casas do Marquês, se fêz a consulta do Conselho, e S.M. respondeu que mandava advertir que evitassem o dano e désse conta" - L. 3 das Cons. de Serv., fl. 84. - B.N. Cod. 178 da Col Pombalina (Alfabeto das Resoluçóes do Cons. da Faz.), fl. 63.

66) - 1653 - junho - 17 - "Consulta do Cons. Ultr. com o decreto sôbre serem condenados os mestres dos navios que carreguem mais dos 4 gêneneros da Companhia geral dos que lhe forem necessários para suas viagens". - A.H.C. - Bahia - Papéis avulsos - 1653.

67) - 1653 - junho - 18 - "Consulta do Cons. Ultr. com a provisão inclusa por que se manda tomar por perdido no Brasil o navio de que é mestre Manuel Alves Pinheiro por ir àquêle Estado sem licença de S.M. nem permissão da Companhia geral". - A.H.C. - Bahia - Papéis avul sos -1653 .

68) - 1653 - junho" - 20 - "Consulta do Cons. Ultr. com o decreto incluso (2 de maio de 1653) sôbre se tomarem por perdidos no Estado do Brasij todos os navios que houverem levado a êle algum dos 4 gêneros da Companhia geral sem seu consentimento ou navegarem sem as armadas". A.H.C. - Bahía - Papéis avulsos - 1653.

69) - 1653 - junho - 17 - "Cópia do papel que deu o Conde de Atouguia, novo governador do Brasil, sôbre várias medidas tocantes ao meThor efeito para o pagamento no Presidio da Bahia, de 20 de junho de 1653" (queixa-se de a $\mathrm{Cin}^{\prime \prime}$. não enviar vinho). Parecer do Conselho Ultramarino no mesmo sentido. - A.H.C. - Bahia - Papéis avulsos - 1653.

70) - 1653 - outubro - 14 - Consulta do Conselho Ultramarino sôbre pedido, do Governador do Brasil, do envio mensal de uma Caravela de socórro com os 4 géneros e sal, pois a Companhia não mandava o suficiente. - A.H.C - Bahia - Papéis avulsos - 1653.

71) - 1653 - dezembro - 9 - "Copia da Nova Consulta, com que o Estado Eccleziastico replicou a resposta, que deu sua Mag. ${ }^{\text {de }}$ á primeira consulta, de sinco de Novembro de 1653, a gual sem perder tempo, the levarão vendo o estado Eccleziastico a resposta de sua Mag. ${ }^{\text {de }}$ que se ve, na seguinte consuita: assentou. que os Bispos capelláo mor, e de Targa, sem demora, the levassem a presente, sobre a revcgação do Alavrá que pedião, que remite a pena de confiscação de beins aos Judeus." - B.E., CVII/1-1, 1. p. 101-104.

72) - 1653-1654 - Cap. 39 dos Capitulos do Estado dos Povos apresentados em Córtes (pedindo a extinção da $\mathrm{Ci}^{\mathrm{a}}$.). E resposta do $\mathrm{Rej}_{\text {p }}$ prometendo estudar o caso. - A.C. - Cod. 583 A. (Coleção de Côries, ñ ${ }^{\circ} 11$. tomo 11 ). fl. 193 V. e $209 \mathrm{~V}$.

73) - S.D. (1653-1654) - Papel pedindo a extinção da $\mathrm{Ci}^{2}$. contra a qual se formulam muitas acusaçōes, em nome dos "povos destes Reynos". A.H.C. - Bahia - Papéis avulsos S/D. - incorporado na caixa do Ano de 1652. 
74) - S.D. (1653-1654) - Papel anónimo, expondo, em 34 parágrafos, queixas contra a $\mathrm{Ci}^{\mathrm{a}}$. e pedindo ao Rei que "mande ver esta materia con to" dos os papeis que sobre ela se deram" - "e examinada a verdade ou se conservará a $\mathrm{Ci}^{\mathrm{a}}$. com mayor assento em seu governo satisfazendo as queixas, ou se escolherá outro mayor mais conveniente para a segurança da navegação, Credito do Reyno, e bem cōmum dos Vassalos". - A.H.C. - Bahia - Papéis avulsos - Incorporado na Caixa do ano de 1652.

75) - 1654 - março - 24 - Carta do provedor da Fazenda do Ric de Janeiro dando conta de terem sido tomados por 5 ou 6 navios corsários holandeses 18 barcos da navegação costeira do Brasil. - A.H.C. - Rio de Janeiro - Papéis avulsos - 1654.

76) - 1654 - abril - 8 - Consulta da Junta dos três Estados "sobre os melhores meios de se continuar a $\mathrm{Ci}^{\mathrm{a}}$. G. do Comercio sem as queixas que de presente há dela". Tem anexa outra de 8-4-1654 em que aconselha a que se derrogue o estanque dos quatro gêneros. - B.A. - Cod. 50-V-35, fls. $131-147$.

77) - 1654 - julho - 11 - "Razões por que parece que não convém à Inglaterra navegarem os seus navios para o Brasil, como se pede, por Antônio de Sousa de Macedo". - B.A. - Cod. 51-V-29, fls. 232 V. - 233 V.

78) - 1654 - julho - 27 - "Cópia da consulta que a Junta da Companhia Geral fêz a Sua Mag. sôbre o fretamento das naus genovesas". A.H.C. - Bahia - Papéis avulsos - 1655, março.

79) - 1654 - setembro - 2 - "Pressupostas as hostilidades no Estado ou na carreira do Brasil resta considerarmos os meios mais suaves para com - favor divino e sem dispèndio da Fazenda Real; não só nos reparemos mas ofendamos." - Francisco Brito Freire, "Sôbre o bom Govêrno e guerra do Brasil", in Ocidente, vol. 9.", págs. 260 a 262 - Lisboa, 1940.

80) - 1655 - janeiro - 19 - Carta do Conde de Atouguia para S. Mag. sôbre os vinhos com que a Companhia falta". - Catálogo dos.Mss. da Bibl. Nac (do Rio), in Annaes da Bibl. Nac do Rio de Jan., - Vol. IV (1877-1878), Rio de Janeiro, 1878, p. 108, fl. $4 \mathrm{~V}$.

81) - 1655 - janeiro - 22 - Carta do Provedor-mor da Fazenda do Brasil a El-Rei, com a Relação das receitas de Fazenda Real na Bahia. A.H.C. - Bahia - Papéis avulsos - 1655.

82) - 1655 - março - 1 - Carta do Conde de Atouguia para S. Mag. sôbre o mal que a Junta corre core os gêneros de seu estanque. - Catálogo ćos Miss. da Bibl. Nac, in Annaes da Bibl. Nac. do Rio de Jan., Vol. IV (1877-1878), p. 108, fl. II V.

83) - 1655 - março - 5 - "Do Conç." Ultramarino - Sobre se remediar o dano que se segue de os nauios que vão ao Rio de Lanr. ${ }^{\circ}$, leuarem mais sal, que o de Estanque". - A.H.C. - Rio de Janeiro. apensos - 1655.

84) - 1655 - março - 18 - Consulta do Conselho Ultramarino sôbre as queixas de irem ao Brasil os navios genovezes, que se achavam no pôrto de Lisboa, e causa delas. - (Resoluçãó de S. Magestade: "A Junta da Companhia mando ordenar náo deixe passar as ditas naus ao Brasil pelas razōes que aponta o Conselho e por outras tambem se me representarem pelo da Fazenda. Lx." a 18 de Março de 655-Rei". - A.H.C. - Bahia - Papéis avulsos -1655 .

85) - 1655 - março - 18 - "Cópia do Decreto de S. Magestade sôbre não passarem ao Brasil os navios próximamente vindos de Gênova, que estão fretados pela Companhia Geral para irem em Companhia da armada." A.H.C. - Bahia - Papéis avulsos - 1655.

86) - 1655 - março - 22 - Da Junta da $\mathrm{Ci}^{\mathrm{a}}$. G. do Comércio reprcsentando a El-Rei sôbre os inconvenientes de não irem ao Brasil as naus genovesas - A.H.C. - Bahia - Papéis avulsos - 1655. 
$87)$ - 1655 - marşo - 27 - Consuita do Conselho Ultramarino Söbre os navios genoveses que a Junta do Comércio manda ao Brasil A.H.C - Bahia - Papéis avulsos - 1655.

88) - 1655 - abril - 7 - Do Cons. Ultramarino: Com a carta do Cou. ${ }^{\circ x}$ do Rio de lan. $^{r 6}$ Dó Luis de Almeida, em que dá conta da gr. ${ }^{\text {de falta }}$ dr vinhos que aly se padeçe". - A.H.C. - R. de Janeiro - apensos 1655.

89) - 1655 - abril - 12 - "Eu El-Rei faço saber a vós Francisco de Brito Freire que ara envio ao Estado do Brasil por general de Armada da Junta do Comércio que hei por meu serviço que no decurso da viagem guardeis o regimento seguinte:" (Com o decreto sôbre o abater de bandeiras no encontro com a Armada Real). - B.A. - Cod. 51-VI-43, fls. 118-120.

90) - 1655 - abril - 13 - "Regimento que Francisco de Brito Freire, Capitão Gerreral da Armada de Comércio, e Frotas do Brasil, manda guardar aos navios de conserva." - Viage da Armada da Companhia do Comércio - Frotas do Estado do Brasil a cargo do general Francisco de Brito Freire, pág. 53 a 64 - B.N. - Reservados 422 Azul.

91) - 1655 - abril - 17 - Queixa que da Companhia fêz o Conselho da Fazenda sóbre o sal e vinhos descaminhados - Regs. no. L. ${ }^{\circ}$ B. das Cons. de Serv., fl. 108 v. - B.N. - Cod. 178 da Col. Pombalina (Alfabeto das Resoingoes do Conselho da Pazenda - fl. 72 v.

92) - 1655 - abril - 24 - "Carta do Conde de Atouguia para $\mathbf{S}$. Mag. sōbre o mal que a Companhia assiste com os 4 géneros por acasião da queixa da Cámara do Rio de Janeiro". - Catál. dos Miss. da Bibl. Nac, in Annaes da Bibl. Nac. do Rio de Jan, vol. IV. (1877-1878), p. 109. fl. 14 v.

93) - 1655 - maio - 4 - Consulta do Conselho Ultramarino com a carta do Conde Governador do Brasil sôbre a falta que nela há dos gêneros da Companbia (tem juntas a carta do Conde, outras dos oficiais da Camara da. Bahia) - A.H.C. - Bahia - Papéis avulsos - 1655.

94) - 1655 - 11 - "Do Conselho Ultramarino: Com a carta que agora se recebe dos officiais da Camara da Bahia Em que se queixão do pouco.vinho com que são socorridos pela Companhia geral". - A.H.C. - Bahia Papéis avulsos - 1655 .

95) - 1655 - junbo - 15 - "Do Conde Gou" do Brasil Sobre as causas $E$ razōes que o mouerão a mandar alguns nauios antes da frota, sem emb: da ordem que the foy, E enuia os papeis que acusa". - A.H.C. Bahia - Papeis avulsos - 1655 .

96) - 1655 - agôsto - 17 - Certidão do escrivão da Fazenda do Rio de Janeiro de se terem. em 1648, arrematado os dizimos da Capitania do Rio. por 3 anos, por 142.000 cruzados (metade em açúcares e metade em fazendas), e os da Capitania da Bahiä, também por 3 anos, por 91.000 сrjzados. - A.H.C. - Kio de Janeiro - Papéis avulsos - 1655.

97) - 1655 - setembro - 24 - Um desembargador nomeado para a Bahia queixa-se de a Companhia the nāo dar passagem. - A.H.C. - Bahia - Papéis Avulsos - 1655.

98) - 1655 - novembro - 29 - "Ultramarino - De S. Mag." Sobre no Brasil hauer taixa nos açucares". - A.H.C. - Bahia - Papéis avulsos. $-1655$.

99) - 1655 - dezembro - 9- O subsiảio dos vinhos da praça do Rio foi arrendado, por 3 anos, por 46.000 cruzados. - A.H.C. - Rio de Janeiro - Papéis avulsos - 1655 .

100) - 1655 - dezembro - 15 - Relação dos estrangeiros que há comerciando no Rio de Janeiro: são 4 , dos quais um vai voltar a Lisboa: dêles só um nâo está autorizado pelo rei, mas mora há anos com o consentimento 
das autoridades locais. - A.H.C. - Rio de Janeiro - Papêis avulsos 1655 (anexo à Consulta de 28 de dezembro).

101) - 1655 - dezembro - 20 - Carta da Câmara do Rio de Janeiro participando que os dizimos daquela praça foram arrematados por $130.500 \mathrm{cru}$ zados os 3 anos, metade em fazendas e a outra metade em dinheiro, para socôrro da infantaria. Mas como todo o dinheiro remetem nesta frota, ficando - Rio sem numerário, pretendem que $c$ arrematante dos dizimos pague em gêneros para sustento dos soldados. - A.H.C. - Rio de Janeiro - Papéis avulsos - 1655 .

102) - 1655 - dezembro - 29 - Carta do Governador do Rio comuvicando terem sido encontrados mais de 100 alqueires de sal descaminbados, cue se dizia pertencer ao General da Armada da Companhia - A.H.C. Rio de Janeiro - Papéis avulsos - 1655.

103) - 1656 - setembro - 8 - Carta do Conde de Atouguia a S. Mag. sôbre os vinhos com que a Companhia falta e aperto em que o povo fica por essa causa. - Catál. dos Miss. da Bibl. Nac, in Annaes da Bibl. Nac. do Rio de Jan., Vol. IV $(1877-1878)$, p. 113, fl. 53.

104) - 1656 - setembro - 16 - A Câmara da Bahia queixa-se de falta de sal. - A.H.C. - Bahia - Papéis avulsos - 1656.

105) - 1656 - novembro - 16 - (Do Conç. Ultramarino: Sobre a falta que no Brasil se padeçe de alguns dos generos de Estanque da Comp. ${ }^{2}$ g. ${ }^{1}$ $e$ se the ordenar os enuie em abundançia, ou se permitir que particulares os leue por sua conta". - A.H.C. - Bahia - Papeis avulsos - 1656.

106) - 1656 - novembro - 23 - Consulta do Conselho de Estado sôbre várias e graves matérias, entre elas o Alvará de isenção do confisco de 1649 e a $\mathrm{Ci}^{\mathrm{a}}$. G. de Comércio do Brasil. - B.N. Cod. 738 da Col. Pombalina, fl. 76 e $82 \mathrm{~V}$. - Foi publicada por Edgar Prestage em separata do Arquivo Histórico Português, que não existe na B.N. nem. na da A.C. Os Conselheiros deram também pareceres individuais, no mesmo sentido do -do Conselho: encontram-se a fl. 91 e segs. do mesmo Código. $\mathrm{O}$ do Mordomo-mor, $D$. João da Silva, datado de 16 do mesmo mês de novembro, está na B.A., Cod. 51-V -41, f1. 48.

107) - 1657 - "Dos offiçiais da Cam. ${ }^{\text {sa }}$ Em que se conformão e remetem ao pareçer da Camara da Bahia sobre a recompença que pedião os Menistros da Com. " g. ${ }^{1}$ sobre os quatro generos que havião de carregar". A.H.C. - Rio de Jan. ${ }^{50}-$ doc. $^{\text {to }}$ n. $^{\circ} 760$.

108) - 1657 - agốsto - 1 - "De Fran. ${ }^{c o}$ Barr. ${ }^{\text {to }}$ g. ${ }^{\text {or }}$ do Brasil: Sobre a demissāo dos generos da Comp." geral, e recompensa do seu estanque". A.H.C. - Bahia - Papéis avulsos - 1657.

109) - 1657 - agôsto - 2 - A Cámara da Bahia pede socôrro de sal. - A.H.C. - Bahia - Papéis avulsos - 1657.

110) - 1657 - agôsto - 4- "Dos officiais da Cámara: Pedem que Smg." mande ordenar aos Deputados de Comerçio lhes acudam com todos os generos de seu contracto, principalmente com vinhos e azeites". - A.H.C. - Babia - Papéis avulsos - 1657.

111) - 1657 - agôsto - 23 - A Câmara da Bahia pede que não falte éste ano a frota, para sairem os açúcares. - A.H.C. - Bahia - Papéis Avuisos - 1657.

112) - 1659 - inneito - 8 - Carta de Francisco Barreto, Governador do Bresil. a S. Mag. ${ }^{a c}$ sôbre não partirem navios. - Catál. das. Mss. da Bibl. Nac, in Annzes da Bibl. Nac. do Rio de Jan., Vol. IV (1877-1878), p. 119. fl. 110.

113) - 1659 - abril - 20 - Carta da Cámara do Rio comunicando a chegada da frota. Os barcos que foram com os que estavam no porto somam 
27; não há-açucares nem para metade; carregam-se primeiro os do combôio como é privilégio da Companhia, depois os particulares que tenham levado vinlio, e os que sobrem ficarăo no Rio aguardando carga e que à Companhia mande uma segunda esquadra para combiá-los. - A.H.C. - Rio de laneiro - Papéis avulsos - 1659.

- 114) - 1659 - abril - 20 - Carta do Governador do Rio, recemchegado na frota da Companhia, participando a miséria que lavra naquela Capitania: nesta safra fizeram-se só 6.000 caixas de açúcar, e não houve quem arrematasse os dizimos, nem o subsídio do vinho. - A.H. C. - Rio de Janeiro - Papéis avulsos - 1659 .

115) - 1659 - junbo - 23 - Cópia do bando que mandou lançar Francisco Barreto. Governador do Brasil; sóbre a proibição de aguardente, vinho de mel e cachaça - A.H.C - Bahia - Papéis avulsos - 1659.

116 - 1659 - agôsto - 23 - "Carta de S Mag. sôbre os navios a gue se concedeu licença, havendo-o proibido sem irem no corpo da Armada. e ordena se the avise das causas que para isso houve". - Catál. dos Mss. de Bibl. Nac, in funnaes da Bibl. Nac. do Rio de Jan., Vol. TV (1877-1878), p. 378, n. 3 .

117) - 1659 - setembro - 15 - Provisão do Conselho Ulltramarino sóbre as penas a gue ficam sujeitos os responsáveis pela vinda de navios fora da frota da $\mathrm{Ci}^{2}$. - A.H.C. - Bahia - Papéis avulsos - 1660 - julho, 24.

118) - 1660 - março - 20 - A Camara da Bahia representa ao Rei que a Companhia, estando obrigada a mandar frota anual, em muitos anos a não envia, com grave prejuizo dos povos. - A.H.C. - Bahia - Papéis avulsos - 1660 .

119) - 1660 - julho - 24 - Provisão real análoga à de 15-9-1659 (doc. 117) - A.H.C. - R. de Jan. ${ }^{\text {ro }}$ - doc. ${ }^{t_{0}}$ n. ${ }^{\circ} 1142$.

120) - 1660 - juiho - 28 - "Carta de S. Mag. para que se guardem swaṣ ordens àcérca da carga e licença de navios estrangeiros que não trouxeram licença particular para isso". - Catál. dos Mss. da Bibl. Nac, in Annaes da Bibl. Nac do Rio de Jan., Vol. IV (1877-1878).

121) - 1660 - setembro - 10 - A Câmara da Bahia pede se the conceda livre a entrada e saida de navios mercantes naquele pôrto, pagando à Companhia o combôio, pois a Companhia, não só não tẹm mandado as duas esquadras anuais pactuadas, mas em alguns anos nem uma, pelo que 0 açúcar, em tanta abundância. vai. com a demora, diminuinde de qualidade $e$ valor, e se perde. - A.H.C. - Babia - Papéis avilsos - 1660.

122) - 1661 - fevereiro - 28 - "Dos Off. ${ }^{\text {aes }}$ da Cam. ${ }^{\text {ra }}$ da Bahia: Sobre se diffirir aos Emb."s. có o pouo da B. a veyo a não se praticar o Aluara, que S. Mag. de m. ${ }^{\text {dou }}$ passar, acerca do acresçentam. ${ }^{\text {to }}$ do comboy, e năo partir nenhum nauio daquele Estado, sem a Armada da Comp.". A.H.C. - Bahia - Papéis avulsos - 1661 .

123) - 1661 - iunho 1 - Dos oficiais da Cámara da Bahia sôbre o não enviar à Junta do Comércio o combóio de navios todos os anos. - A.H.C. - Bahia - Papéis avulsos - 1661.

124) - 1661 - junho - 12 - Sôbre se conceder aos contratadores dos dizimos que possam mandar cada ano 6 navios com carga de açúcares durante o tempo do seu contrato, e za forma das condjções déle, sem embargo da lei (mandada observar pelo alvará de 16-7-1660. publicado na Bahia cm março de 1661) passada a favor da Companhia Geral para que não possa vir navio algum fora da frota. - A.H.C. - Bahia - Papéis avulsos - 1661 .

125) - 1661 - julho - 24 - Carta de Francisco Barreto, Governador Geral do Brasil, ao Rei, historiando o que se tem passado com a aguardente da terra. cachaça e vinho de mel: em virtude de representaçóes dos comer- 
ciantes e outros, foram essas bebidas proibidas no Brasil por carta régia de 21-2-1647; com a libertação do comércio dos gêneros, de que a Companhia tivera o estanco, suspendeu-se tal proibição; faltando vinhos no Brasil c zerificando-se frequientes desordens atribuidas a embriagues com as bebidas da terra, a Cámara da Bahia, convencida de que assim animaria os mercadores da metrópole a exportar vinhos para o Brasil, pediu de novo a proibição daquelas bebidas, ào que êle Governador deferiu; tendo, porém, mudado os oficiais da Câmara, esta, alegando não terem afizal chegado vinhos (sôbre os quais é lançado o subsidio para pagamento da infantaria da praça), impetra licença para arrendar as referidas bebidas da terra; êle Governador, tendo reunido e ouvido uma Junta para o efeito, autorizou o contrato por um ano; deseja que - Rei dê instruçóes sóbre o assunto; êle Governador entende que se proibam as bebidas da terra e se exviem vinhos para o Brasil. - A.H.C. - Babia Papéis avulsos - 1661.

126) - 1661 - novembro - Carta do Ouvidor Geral do Rio de Janeiro sôbre os 26.000 cruzados que couberam ao Rio no imposto extraordinário que - Rei pediu ao Brasil: serạ̃o pagos com 13.000 arrobas de açúcar branco (a 2 cruzados) por ano, os anos começarão em janeiro. - A.H.C. - Rio de Janeiro - Papeis avulsos - 1661.

$127)$ - 1661 - dezembro - 8 - Sôbre não quererem os administradores da Companhia pagar o frete de um patacho com aviso para o Reino. A.H.C. - Bahia - Papéis avilsos - 1661.

128) - $166 \hat{i}$ - dezembro - 19 - Carta régia proibindo a venda no Brasil de fazendas de naus da India arribadas (outras identicas de 3-3-1665. $17-6-1667,18-9-1670,13-2-1672,2-3-1672,22-3-1677,10-3-1710,11-3-1711$, 20-3-1734, 17-4-1738, 24-6-1743, 9-10-1749). - Sumários em João Pedro Ribeiro, fndice Cronológico, vol. III, p. 28 e 39.

129) - 1662 - janeiro - 25 - Provisão permitindo a 2 navios portuguêses de 300 toneladas cada ir ao Brasil e déle voltar fora da frota. A.H.C - Bahia - Papéis avulsos - 1662.

130) - 1662 - janeiro - 27 - Carta régia para que se guardem as suas ordens àcêrca de navios estrangeiros que vão ao Brasil sem licença esper cial - Catálogo dos Mss. da Bibl. Nac., in Ananes da Bibl. Nac., do Rio de Jan., vol. IV $(1877-1878)$, p. 382, n. $^{\circ} 3 .^{\circ}$.

131) - 1662 - janeiro - 28 - Autorização a navio inglês para ir ao Brasil - (Outra em 7 de fevereiro). - A.H.C. - Bahia - Papéis avulsos -1662 .

132) - 1662 - abril - 17 - Tendo o Rei concedido, pelo Conselho da Fazenda, licença a Abraão Jacob para ir ao Brasil com uma nau inglêsa, - Conselho Ulitramarino protesta, já por o assunto ser da sua competência e jurisdição, já por ser contra o decreto proibitivo de 20-5-1662 - A.H.C. Bahia - Papéis avulsos - 1662.

133) - 1662 - maio - 11 - Consulta do Conselho Ultramarino com parecer contrário a requerimento de autorização para ir ao Brasil um patacho fora da frota. - A.H.C. - Bahia - Papéis avulsos - 1662.

134) - 1662 - maio - 20 - "Por justas consideraçōes de meu serviço houve por bem resolver se não concedam daqui em diante licenças para frem nem voltarem navios estrangeiros e portuguêses do Brasil, fora do corpo das armadas; e se recolham as de que não estiverem passados pela Chancelaria os ajvarás delas. O Conselho Ulltramarino o faça executar daqui em diante nesta conformidade, não me propondo semelhante requerimentos. Em Lisboa, a 20 de maio de 1662. Rainha". - A.H.C. - Bahia - Papéis avulsos $-1662$.

135) - 1662 - novembro - 27 - Seqüestro, consoante as instruções gerais anteriorcs, de 1 patacho ingles que chegou ao Rio com negros que pre- 
tcndia tracar por açücar. - A.H.C. - Rio de Janeiro - Papêts avulsos - 1662

136) - 1662 - novembro - 28 - Carta do Govemador do Rio de Janeiro pedindo se ondene ao contratador do sal que envie muito nos próximos barcos, en virtude da grande falta que se experimenta no Rio. - A.H.C. Rio de Janeiro - Papéis avulsos - 1662

137 - 1662 - novembro - 28 - Carta do Governador do Rio comu. uicando que, por exigêacias dos arrematantes do subsidio do vinho e dos dizizoos ("donde se pagam as ordinárias eclesiásticas, ordenados de justiça, gente de guerra, mais despesas e gastos das folhas"), lhes concedeu poderem mandar 1 barco por ano cada um déles às Ilbas ou ao Reino, fora da frota. Ao Conselbo Ulltramarino parece que a condição é nula, devendo o contrato subsistir sern ela. - A.H.C. - Rio de Janeiro - Papéis avulsos - .1662.

138) - 1662 - novembro - 29 - Consulta do Conseltho Ultramarino concordando com a sugestão do Governador do Rio de Janeiro de se the darem poderes para, pelas justiças ordinárias, com assistência da Companhia, julgar a gente das frotas da mesma Companhia que no Rio cometa delitos, pois atê agora essa gente delinguia impunemente, já que, por ter foro privativo, năo podia ser castigada no Brasil, e na Metrópole de fato a nāo castigavam. A.H.C. - Rio de Janeiro - Papéis avulsos - 1662.

139) - 1663 - março - $28-O$ Governador do Rio de Janeiro pede pocieres para pôr gurardas nos barcos da Companhia, que os nāo admite, assim podendo fugir, com as fazendas gue levam para o Brasil, ao imposto de $2 \%$ sôbre as mercadorias entradas que a Camara estabeleceu para pagamento, durante 16 anos da contribução anual de 26.000 cruzados que ao Rio coube no ratêio do socôrro especial pedido pelo Rei ao Brasil. No Conselho Ultramarino opina-se que a Câmara nâo pode lançar tal impôsto, que é prerrogativa real. - A.H.C. - Rio de Janeiro - Papéis avulsos - 1663.

$140-1663$ - abril - 9 - "Carta de S. Mag. para nāo se consentir se impeça a venda dos vinhos nem se faça estanque de gênero algum dos de Companhia". - Catal. dos Mss. da Bibl. Nac. in Amaes da Bibi. Nac do Rio de. Jan., vol. IV (1877-1878), p. 388, n. 97.

141) - 1663 - julho - 21 - Carta do General da Armada da Compantia, preso em S. Juliāo, e Consulta do Conselho Ultramarino, das quais se vê que hourve grande detnora da frota da Companhia no Rio de Janeiro, alego-se que por falta de açúcares para carregar, por pouco antes os haverem carregado barcos que não vieram para o Reino; e que os direitos na.Bahia foram de mais de 45.000 cruzados. - A.H.C. - Rio de Janeiro - Papéis avulsos -1663 .

142) - 1663 - julho $-28-O$ mesmo assunto do doc. 138. Despacho do Rei, dizendo que não se pode revogar a Instituição da Companhia, mas que, se os cabos desta não castigarem a sua gente, se lhe diga a êle Rei para yrovidenciar (veio o Rei a satisfazer em pate o pedido do Governador do Rio de Janeiro, referido no doc. 138, por despacho de $24-$ abril -1668 , lançado sa consulta do Conselho Ultramarino de 9 de março de 1668) A.H.C - Rio de Janeiro - Papeies avulsos - 1663.

143) - 1663 - agôsto - 29 - Carta da Câmara da Bahia sôbre a junta que se fêz em presença do Conde Vice Rei àcêrca de se diminuir a imposição dos vinhos e se extinguirem as bebidas da terra. - A.H.C. - Bahia Papéis avulsos - 1663.

144) - 1663 - setembro - 1 - "Do Cons: Ultramarino: Sabre se não impedir nas Capitanias da B. Pern. ${ }^{c o}$. Illheos, e Rio de Janeiro o corte de pao Brasil, que está concedido a Comp." do comercio, e vay a consulta que se acusa": - A.H.C. - R. Jan. - doct." n." 955. 
145) - 1664 - janeiro - 22 - Memoria dos lugares, e off. de Justiça que ha nesta praça do Rio de Janeiro para S. Mg. ${ }^{\text {do }}$ mandar ver no seu Conselho Ultramarino". - A.H.C. - Rio de Janeiro - doc. n." 971 e 972.

146) - 1664 - janeiro - 23 - "Rellação que V. Mg. me mandou pedir dos postos melitares offissios de fazenda e justiça por sua carta de 16 de Fev. ${ }^{\text {ro }}$ de 1663". - A.H.C. - Rio de Janeiro - Doc. n. 975 e 976.

147) - 1664 - janeiro - 26 - Consulta do Conselho Ultramarino contrária à validade de condição, posta no contrato de arremataçáo dos dízimos do Rio de Janeiro, de poder o arrematante enviar urn navio às Illas ou ao Reino fora da frota. Está junta a provisão de 24-7-1660 proibindo a navegação fora da frota comboiada pela Companhia - A.H.C. - Rio de Janeiro - Papéis avulsos - 1664.

148) - 1664 - janeiro - 30 - Sôbre não passarem ao Brasil navios estrangeiros sem especial ordem de S. Mag. - A.H.C. - Bahia - Papéis avulsos - 1664 .

149) - 1664 - fevereiro - 25 - Consulta de que sè vê estar o sal para o Brasil arrendado a Luiz de Pina Caldas e Manuel de Castro - A.H.C. - Bahia - Papéis avulsos - 1664.

150) - 1664 - majo - 31 - Notificação que se fêzz aos mestres dos navios que agora chegaram do Brasil fora do Corpo da armada do combóio. A.H.C. - Bahia - Papéis avulsos - 1664 .

151) - 1664 - junho - 10 - Autorização para irem todos os anos alguns navios da Madeira ao Brasil fora do combóio. - Catál dos Mss. da Bibl. Nac, in Annaes da Bibl. Nac. do Rio de Jan, Vol. IV (1877-1878), p. $385, n^{\circ} 75$.

152) - 1664 - junho - 17 - Sôbre se autorizar a ida de 3 navios com açúcares da Bahia à llha da Madeira, fora do comboio da $\mathrm{Ci}^{\mathrm{z}}$. - Com parecer desfávorável do Conselho Ultramarino. - A.H.C. - Bahia - Papéis avulsos - 1664 .

153) - 1664 - julho - 10 - Portaria que se passou ao Ourvidor Geral do Crime dêste Estado para que enquanto não carregarem as naus da Armada da Companbia Geral não carregue outro navio algum." - Catál dos Mss. da Bibl. Nac, in Annaes da Bibl. Nac do Rio de Jan, vol IV (1877i878), p. 233, fl. $53 \mathrm{~V}$.

154) - 1664 - agôsto - 19 - Carta do Conde Vice Rei do Brasil sôbre as embarcações que mandou para o Reino fora do corpo da Armada, tendo o Rei ameaçado con castigo rigoroso pelo fato, em virtude de queixa da Companhia. - A.H.C. - Bahia - Papéis avulsos - 1664.

155 ) - 1664 - novembro - 14 - Sôbre o mesmo assunto do anterior. - A.H.C. - Bahia - Papéis avulsos - 1664.

156) - 1664 - novembro - 22 - "Do Conç. Ultramarino: Sobre o que escreve o Conde de Obidos V. Rey do Brasil, acerca do córte do pao brasil, que pertença á Comp." Geral". - A.H.C. - Bahia - Papéis avulsos -1664 .

157) - 1664 - dezembro - 15 - "Do Conselbo Ultramarino: o Gou. do Rio de Janr. ${ }^{\circ}$ P. ${ }^{\circ}$ de Mello dá conta do grande dano que resulta aquella Cap." em se nāo conceder ao Contratadores dos Dizimos licença para poderem manciar nauios fora do corpo da armada a llha da Madr.", e uay a const." que se acusa". - A.H.C. - Rio de Janr..$^{\circ}$ Doct. ${ }^{\circ} .^{\circ} 965$.

158 ) - 1665 - janeiro - 17 - "Carta de S. Mag. àcêrca da cabrança de tudo o que neste Estado se estiver devendo à Companhia Geral do Co. Irércio". - Catál. dos Mss. da Bibl. Nac, in Annaes da Bibl. Nac. do Rio de Jan., vol. IV $(1877-1878)$, p. $396, \pi .^{\circ} 163$.

159) - 1665 - janeiro - 17 - "Carta de S. Mag. àcêrca do favor que se há de dar aos oficiais da Junta e cousas da Companhia Geral e liberdade que hãăo de ter seus administradores no fazer o pau brasil". - Catál. dos Mss. 
da Bibl. Nac, in Annaes da Bibl. Nac. do Rio de Jan., vol. IV (1877-1878), p. $396, n . " 161$.

160) - 1565 - janeiro - 25 - Alvará aprovando o contrato de 24 de setembro de 1564. para ter inicio em 1 de janeiro de 1665 , pelo qual foi concedido por 6 anos às Cámaras do Brasil o estanco do sal por 4.000 cruzados por ano que pagariam para a Fazenda Real. - A.H.C. - Bahia - Papéis avulsos - 1665 - Junho - 26.

163) - 1663 - fevereiro - 23 - "Carta de S. Mag. àcêrca de se deixar acs Administradores da Companbia o corte e preço do pau Brasil, proibindo-se por ordens antecedentes o intrometerem-se os Governador e Capitães mores nesta matétia, que só toca à Companhia Geral, cujo regimento manda se observe inviolavelmente". - Catál dos Mss. da Bibl. Nac., in Annaes da Bibl. do Rio de Jan., vol. IV $(1877-1878)$, p. 396, n. 160.

$162 j$ - 1665 - agôsto - 12 - "Sobre se guardar a prouizão que se passou p." não virem nauios do Brasil fora da frota da comp. geral". (Carta do Procurador Geral da Cidade da Bahia e minuta do despacho do Conselho Ultramarino). - A.H.C. - Bahia - Papéis avulsos - 1665.

163) - 1665 - outubro - 23 - Sóbre o que pede Pedro de Melo. Governadot do Rio de Janeiro (autorização para vir em navio fora da frota): A.H.C. - R. de Jan. ${ }^{\text {to }}$ - doc." n. ${ }^{\circ} 103 \%$.

164) - 166 - março - 10 - A Cámara do Rio pede diminuição no donativo anual de 26.000 cruzados, pelo estado de miséria em que se encontram seus moradores. - A.H.C. - Rio de Janeiro - Papéis avulsos 1666.

165) - 1666. - maio - 8 - "Carta de S. Mag. sōbre a cobrança das dividas da Companhia Geral do Comércio". - Catál dos Mss. da Bibl. Nac, in Annaes da Bibl Nac do Rio de Jan., vol. IV (1877-1878), p. 393, n. 182.

166) - 1667 - dezembro - 20 - "Sobre o que escreue o g. ${ }^{\circ r}$ do Brasil acerca dos Administradores da comp. geral darem as embarcaçōes n. rus (necessáxias) p." os auizos que se ouuerem de enuiar a este reino". - A.H.C. - Bahia - Papéis avulsos - 166\%.

167 - 1670 - junho 4 - Licença para irem ao Brasil todos os anos alguns navios dos Açores fora do combóio. - Catál. dos Miss. da Bibl. Nac., in Annaes da Bibl. Nac do Rio de Jan., vol. IV $(1877-1879)$, p. 386, n. 76.

168) - 1671 - janeiro - 31 - "Do Cons. Uitramarino: Sobre o que representāo os Procuradores da B." e Rio de Jan. ${ }^{\mathrm{To}}$ em razão das molestias que aqueles pouos padessem, com as opresões dos generáes Almirante e off." das frotas, por suas insolençias". - A.H.C. - R. ${ }^{\circ}$ de Jan. ${ }^{\text {ro }}$ - Doct. ${ }^{\circ}$ ก." 1169.

169j - 1671 - janeiro - 31 - "Do Conç. Ultramarino: Sobre o que representão os Procuradores da Bahia, e Rio de Jan. ${ }^{\circ}$, acerca dos danos que se seguem à conservaçāo daquellas Cap. ${ }^{n t a s}$ de se consederem licenças a navios p." virem fora da frota". - A.H.C. - R." de Jan. ${ }^{\mathrm{r}}$ - doc. ${ }^{10}$ p. ${ }^{\circ} 1135$.

170) - 1671 - fevereiro - 16 - "Do Conç. Ultramarino: Sobre o que representáo os Procuradores da Bahia, e Rio de Jen. ${ }^{\circ 0}$, acerca da forma que deveto tomar as Frotas, em irem e virem do Brasil". - A.H.C. - R० de Jan. ${ }^{\text {*o }}$ - doc. ${ }^{* 0}$ n..$^{\circ} 1339$.

171) - 1671 - iulbo - 18 - Consulta sôbre o regimento da frota. A.H.C. - R." de Jant." - doc. ${ }^{10}$ n. ${ }^{\circ} 1140$.

172) - 1671 - julho - 18 - Disposiçâo real permitindo que venham do Brasil fora da frota os navios de 20 ou mais peças. - A.H.C. - R. de Jan. ${ }^{\text {To }}$ - n..$^{\circ} 1141$.

173) - 1673 - maio 15 - Do Concelho Ultramarino: Sobre a ordem que pede o Procurador da Cap. do Rio de Janeiro frey Mauro da Assunpção 
para que os exportadores de açucar possam escolher 0 barco em que pretendem carregar". - A.H.C. - R. ${ }^{\circ}$ de Jan. ${ }^{\circ 0}$ - doc. ${ }^{\circ}{ }^{\circ} .^{\circ} 1187$.

174) - 1674 - novembro - 29 - "Do Conç." Ultramarino: Sobre as ordens que se passão plo mesmo Cons. ${ }^{\circ}$, p." os Gou. ${ }^{\text {res }}$, e Procuradores da faz." do Brasil entregarem aos Administradores da Junta do Comercio, o dispedindo das muniçōes que se envião aquelle Estado; e não se expedirem outra's ordens em contr. pla Secretar. ${ }^{\circ}$ de Estado". - A.H.C. - R. 'de Jan. ${ }^{\text {ro }}$ doc. $^{\text {to }}$ n. ${ }^{\circ} 1247$.

175) - 1680 - maio - 6 - de "Alvará por que V. Alteza há por bem de largar à Junta do Comércio do Brasil, o comércio e administração da Costa da Mina, para que o administre, com o mesmo poder, jurisdição e direção com que faz o do Brasil, pela maneira acima declarada". - A.C. - Res. 11.2.9 (Coleçāo da Legislação de Trigoso, vol. $9^{\circ}$, n. $^{\circ} 64$ ).

176) - 1681 - "Consignações que vão nos Almoxarifados, Alfandegas, $\&$ Thezr. ${ }^{\circ s}$ deste Reyno.

As quais importão ao todo

$427.383 \$ 954$

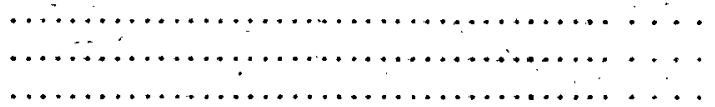

Tem de Consignaçam a Junta do Comercio $p .^{\circ}$ se

pagar dos reditos atrazados, que se lhe devão no

Thr. do Tabaco

devião .......................... 36.009\$000".

- B.E. - Cod. CXIH/2-28.

177) - 1685 - janeiro - 8 - "Carta de El-Rei ao Governador do Rio de Janeiro sôbre os soldados do Terço da Junta do Comércio Geral que ali desertam". - A.H.C. - R. de Janeiro - Doct. ${ }^{\circ}$ n. 11519.

178) - 1688 - fevereiro - 28 - "Lei porque V.M. há por bem que todo o açúcar, que vier das Conquistas para êste Reino se pese em um trapiche, donde haverá Ver-o-peso: e que nas caixas se ponha marca de fogo, para se conhecer a qualidade de que é o açucar, na forma acima declarada, com as penas conteudas nela". - Coleção de Leis - 1539 a 1699, in B.N.. Rs. , $8 \div-A$, fls. $174-175$.

179) - 1695 - outubro - 31 - Alvitre a El-Rei para que se fabriquem fragatas no Rio de Janeiro. Com despacho mandando consultar a Junta do Comércio. - B.E., Cod. CXVI/2-63, 26.

180) - 1697 - junho - 1 - Alvará determinando que; para evitar descaminhos do pau brasil, corra o estanque dêle por conta da Fazenda que se administra pelo Tribunal da Junta do Comércio, e que se o não possa carregar senão em navios da mesma Junta. - Coleção de Leis - 1639-1699, in B.N., Res. 84-A.

181) - 1703 - janeiro - 15 - "Copia - Papel que deu ao Governador do. Rio de Janeiro Dom Alvaro da Sylveira o Provedor da Faz." real sobre se mandar fazer a casa dos quintos na casa da moeda". - A.H.C. Rio de Janeiro - Doc. n. 2679.

182 - 1703 - fevereiro - 27 - "Resolução que se tomou sôbre o ficar a casa dos quintos na mesma casa da Alf." em que está até resolução de S. Mag." ${ }^{\text {" }}$ - A.H.C. - Rio de Janeiro - Doc. n. 2680.

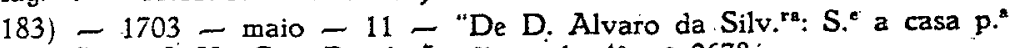
os quintos". - A.H. C. - R..$^{\circ}$ de Jan..$^{\circ 0}$ - doc. ${ }^{\circ} 00^{\circ} 2678$.

184) - 1703 - setembro - 7 - "Do Conselho Ulitramarino: Sobre o que escreve o Gouernador do Rio de Janeiro acerca da Casa que se deve 
fazer de nowo para o lawor da moeda, e vay a carta que se acusa". A.H.C. - R. de Jan. ${ }^{\text {.0 }}$ - doc. ${ }^{\mathrm{to}}$ n. $^{\circ} 2677$.

185) - 1720 - (?) - "A nova Companhia do Comércio que intentam fazer os homens de negócio da praça de Lisboa é debaixo das condições seguintes, que hão de ser confirmadas por El-Rei". - B.N. - Cod. 495 da Col. Pombalina, fls. $45-48$.

186) - 1728 - novembro - 23 - "Relação dos contratos, que se criaráo, e estabelecerão pella Camara do Rio de Janeiro, motivo, origem, e aplicação delles; com declaração dos que se administrāo pella Provedoria da Faz." real. - A.H.C. - Rio de Janeiro - Doc. n. 608 . 